

\section{DISCLAIMER}

This report was prepared as an account of work sponsored by an agency of the United States Government. Neither the United States Government nor any agency Thereof, nor any of their employees, makes any warranty, express or implied, or assumes any legal liability or responsibility for the accuracy, completeness, or usefulness of any information, apparatus, product, or process disclosed, or represents that its use would not infringe privately owned rights. Reference herein to any specific commercial product, process, or service by trade name, trademark, manufacturer, or otherwise does not necessarily constitute or imply its endorsement, recommendation, or favoring by the United States Government or any agency thereof. The views and opinions of authors expressed herein do not necessarily state or reflect those of the United States Government or any agency thereof. 


\section{DISCLAIMER}

Portions of this document may be illegible in electronic image products. Images are produced from the best available original document. 


\section{UNITED STATES DEPARTMENT OF THE INTERIOR}

CECIL D. ANDRUS, Secretary

\section{GEOLOGICAL SURVEY}

H. William Menard, Director

Library of Congress Cataloging in Publication Data

Stauffer, R. E.

Chemical studies of selected trace elements in hot-spring drainages of Yellowstone National Park.

(Geohydrology of geothermal systems) (Geological Survey professional paper ; 1044-F)

Bibliography: p. F18-F20.

Supt. of Docs. no.: I 19.16:1044-F

1. Trace elements. 2. Geochemistry-Yellowstone National Park.

3. Hot springs-Yellowstone National Park. 4. Yellowstone

National Park. I. Jenne, Everett A., 1930- joint author.

II. Ball, J. W., joint author. III. Title. IV. Series. V. Series:

United States. Geological Survey. Professional paper 1044-F.

QE516.T85S76 $\quad 551.2^{\prime} 3^{\prime} 0978752 \quad 79-607187$

For sale by the Superintendent of Documents, U.S. Government Printing Office Washington, D.C. 20402

Stock Number 024-001-03294-5 
CONTENTS

\begin{tabular}{|c|c|c|}
\hline P & $\begin{array}{l}\text { Page } \\
\text { F1 }\end{array}$ & Results-Continued \\
\hline troduction & 1 & $\begin{array}{l}\text { Kesurts-Contunuea } \\
\text { Statistical definitions }\end{array}$ \\
\hline Acknowledgments -.-.-... & 2 & Octopus and Azure Springs \\
\hline ample sources & 2 & Oxidation and diffusion processes \\
\hline Lower Geyser Basin ......... & 2 & - \\
\hline Yellowstone Canyon & 2 & Unnamed sulfide-bearing springs in Yellowstone Canyon \\
\hline Madison River system & 3 & Madison River system \\
\hline Sampling methods & 4 & Sorption controls on arsenic in geothermal waters \\
\hline Analytical methods & 4 & Arsenic flux of the Madison River \\
\hline Results & $\mathbf{5}$ & Potential ecological significance of arsenic \\
\hline Data reliability & 5 & Conclusions \\
\hline Pure analytical error & 5 & References cited - \\
\hline$x_{0}$ & 6 & \\
\hline
\end{tabular}

\section{ILLUSTRATIONS}

Page

FIGURE 1. Sketch map showing rivers and major hydrothermal areas sampled in Yellowstone National Park, Wyo -.........-...- F3 2. Schematic diagram of Madison River and Yellowstone Canyon sulfide-bearing mixed spring systems and

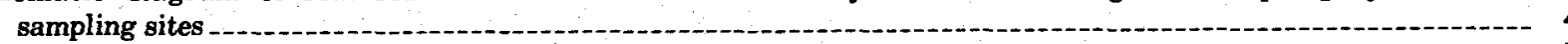

3. Physical and chemical parameters of two hot springs and their drainages

4. Concentration factors of several parameters for two hot springs and their drainages

\section{TABLES}

TABLE 1. Analytical precision of solute data

2. Chemical and physical parameters of Octopus Spring and its drainage 6

3. Chemical and physical parameters of Azure Spring and its drainage

4. Selected physical and chemical properties of additional hot waters 11

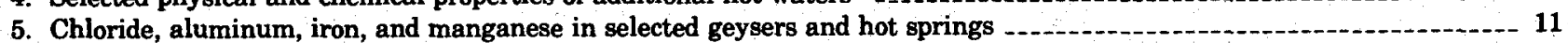

6. Chemical and physical parameters of Calcite and two other unnamed sulfide-bearing springs in Yellowstone Canyon with the drainage of the mixed spring system

7. Estimated solute losses following mixing in Yellowstone Canyon mixed spring and Madison River systems

8. Chemical and physical parameters of the Madison River drainage 


\title{
CHEMICAL STUDIES OF SELECTED TRACE ELEMENTS IN HOT-SPRING DRAINAGES OF YELLOWSTONE NATIONAL PARK
}

\author{
By R. E. Stauffer, ${ }^{1}$ E. A. Jenne, and J. W. Ball
}

\section{ABSTRACT}

Intensive chemical studies were made of $\mathrm{S}(-\mathrm{II}), \mathrm{O}_{2}, \mathrm{Al}, \mathrm{Fe}, \mathrm{Mn}, \mathrm{P}$, $\mathrm{As}(\mathrm{III}), \mathrm{As}(\mathrm{V})$, and $\mathrm{Li}$ in waters from two high-Cl, low $\mathrm{Ca}-\mathrm{Mg}$ hotspring drainages in the Lower Geyser Basin, a warm spring system rich in $\mathrm{Ca}$ and $\mathrm{Mg}$ in the Yellowstone Canyon area, and the Madison River system above Hebgen Lake. Analyses were also made of other representative thermal waters from the Park.

Soluble $\mathrm{Al}$ concentrations were generally low $(<100 \mu \mathrm{g} / \mathrm{L}$ and frequently $<50 \mu \mathrm{g} / \mathrm{L}$ ) except in Azure Spring in the River Group of Lower Basin $(\sim 500 \mu \mathrm{g} / \mathrm{L})$. Approximately 90 percent of the $\mathrm{Al}$ was found to precipitate in the upper drainage channel and nonflowing satellite pool of Azure Spring and was accompanied by an 8 percent $(250 \mu \mathrm{g} / \mathrm{L})$ loss of the $\mathrm{Li}$ flux.

Solute $\mathrm{Fe}$ and $\mathrm{Mn}$ concentrations were typically very low $(<10$ $\mu \mathrm{g} / \mathrm{L})$ in the alkaline high-Cl thermal waters. Soluble reactive $\mathrm{P}$ and total $P$ concentrations were low $(<2 \mu \mathrm{g} / \mathrm{L}$ as $\mathrm{P})$ in all of the high-Cl, $\mathrm{HCO}_{3}^{-}$-buffered hot springs. The Firehole, Gibbon, and Madison Rivers contained 4 to $6 \mu \mathrm{g} / \mathrm{L}$.

Total solute As acted conservatively in the alkaline drainages studied, including the Firehole-Madison River. However, the $\mathrm{As}(\mathrm{III}) / \mathrm{As}(\mathrm{V})$ ratio was strongly bimodally distributed $(\sim 50$ or $<0.1)$ according to whether dissolved $\mathrm{S}(-\mathrm{II})$ or $\mathrm{O}_{2}$ was dominant in the thermal water. Oxidation of As(III) proceeded rapidly at the elevated temperatures $\left(30^{\circ}\right.$ to $\left.90^{\circ} \mathrm{C}\right)$ in the drainages, but only following the oxidation of dissolved S $(-$ II $)$. In contrast to the Firehole River, approximately 60 percent of the thermally related As flux in the Gibbon River drainage basin is precipitated prior to the Gibbon's conflu. ence with the Firehole at Madison Junction. The As/P atomic ratio is typically $\sim 500$ for the alkaline hot-spring waters, and $\sim 15$ during base-flow conditions on the Madison River. The differential toxicities of the As species, the variable As(III)/As(V) ratios, and the very large As/P ratios all suggest that As may be ecologically important in the Park's thermal waters.

\section{INTRODUCTION}

The trace-element chemistry of hot springs and geothermal drill-hole waters has attracted interest in the past because of the hypothesized relationships between hydrothermal solutions and base metal ore genesis (Barnes, 1967). Trace-element chemistry is also valuable in assessing both subsurface physicalchemical conditions and potential environmental impacts of geothermal commercial exploitation.

The principal solutes present in hot-water- dominated geothermal fluids, $\mathrm{SiO}_{2}, \mathrm{Na}, \mathrm{K}, \mathrm{Li}, \mathrm{Ca}, \mathrm{Mg}$, $\mathrm{Cl}, \mathrm{HCO}_{3}, \mathrm{SO}_{4}, \mathrm{~F}$, and $\mathrm{B}$, have been investigated in diverse geothermal settings throughout the world (Ellis, 1970). The concentrations of the prominent nonconservative solute species $\left(\mathrm{SiO}_{2}, \mathrm{Ca}, \mathrm{Mg}, \mathrm{F}, \mathrm{K}\right)$ have been rationalized using mineral equilibria models (Ellis, $1967,1970,1973)$. The rare alkalis, $\mathrm{Cs}$ and $\mathrm{Li}$, and the metalloid, As, are regarded by Ellis (1970) as weakly conservative because they are sometimes partially precipitated in the epithermal zone. The elements $\mathrm{Cl}, \mathrm{Br}$, and $B$ are considered highly conservative, once dissolved in the hot circulating water.

Ellis $(1969,1973)$ interprets the low levels of Fe, Mn and $\mathrm{Al}$ in $\mathrm{HCO}_{3}$-buffered hot waters as convincing evidence that solubility controls are acting on these geochemically abundant elements. Sulfides of $\mathrm{Fe}, \mathrm{Cu}$, $\mathrm{Pb}$, and $\mathrm{Zn}$ are being deposited at depths of 250 to 800 $\mathrm{m}$ at both Waiotapu and Broadlands, New Zealand (Browne, 1969), from hot water containing up to 1.7, 10 , and $2.2 \mu \mathrm{g} / \mathrm{L}$ (micrograms per liter) of the latter three elements, respectively (Ritchie, 1973). Heavymetal mineralization at depth is largely absent at Wairakei, although some pyrrhotite (FeS) is found. The abundant mineralization at Broadlands is attributed to the high concentration $(120 \mathrm{mg} / \mathrm{L})$ of solute sulfide species, S(-II), in the effluent. At Wairakei, $\mathrm{S}(-\mathrm{II})$ is $12 \mathrm{mg} / \mathrm{L}$, or about one order of magnitude larger than most of the values reported for Yellowstone (Thompson and others, 1975) or Steamboat Springs, Nevada (White, 1967). Spectrographic analyses of evaporated residues of typical alkaline Yellowstone thermal waters (Rowe and others, 1973) indicate levels of transition series elements comparable to New Zealand thermal waters (Ellis, 1969).

Greater than milligram-per-liter concentrations of $\mathrm{Fe}, \mathrm{Mn}$ and $\mathrm{Al}$ commonly occur in "acid-sulfate-type" geothermal waters as a result of attack on the country

Present address: Water Chemistry Laboratory, University of Wisconsin, Madison, Wisconsin 58706. 
rock by sulfuric acid (White and others, 1971). The sulfuric acid is thought to be derived from oxidation of $\mathrm{S}(-\mathrm{II})$ in the near-suface zone.

White (1967) noted that the semimetallic elements $\mathrm{As}, \mathrm{Sb}$ and $\mathrm{Hg}$ are especially mobile in geothermal systems and are present at relatively high concentrations. $\mathrm{Sb}$ and $\mathrm{Hg}$ sulfides are epithermally deposited along with sinter at Steamboat Springs (White, 1967) and at Broadlands (Weissberg, 1969). Neither of the two prominent arsenic sulfides (orpiment, $\mathrm{As}_{2} \mathrm{~S}_{3}$; realgar, AsS) was observed as a discrete mineral, either in the sinter or at depth in drill cuttings. However, As coprecipitated with stibnite $\left(\mathrm{Sb}_{2} \mathrm{~S}_{3}\right)$ as $\sim 5$ percent impurity (Weissberg, 1969). Weissberg noted that $\mathrm{Tl}, \mathrm{Ag}, \mathrm{Au}$, and $\mathrm{Hg}$, in addition to As, were highly enriched in stibnite in the near surface at the Broadlands. Arsenopyrite in minor amounts has been ejected from a Wairakei drillhole. Weissberg (1969) estimated that less than $10^{-4}$ percent of the As flux from a Broadlands drill-hole discharge was precipitated with the amorphous silica, in contrast to 0.5 to 5 percent of the Sb.

Research on the thermally related fluxes of $\mathrm{Hg}$ and As into the Waikato River (Axtmann, 1975) was motivated by geothermal power development in the Taupo Basin, New Zealand. Elevated levels of both As and $\mathrm{Hg}$ were found in the sediments of Lake Aratiatia below the discharge of theWairakei effluents. The macrophytic dominant in Lake Aratiatia, Lagarosipon major, featured an As concentration factor (over the Waikato River concentration of $39 \mu \mathrm{g} / \mathrm{L}$ ) of 5,300 (Reay, 1973). However, because of the very large As flux in the Waikato (estimated at 158 metric tons/yr, Axtmann, 1974), less than 4 percent of the As entering the river system is removed by vegetation before discharge into the sea.

The attenuation of geothermally related trace elements in hot-spring drainages and receiving waters has apparently not been previously studied in the United States. Boylen and Brock (1973) and Zeikus and Brock (1972) reported chemical analyses of the Firehole River (Yellowstone Park, Wyo.) at stations selected to show qualitative influences of hot-spring influents on the river biota. Among the elements which can properly be thought of as geothermal trace elements, only $\mathrm{PO}_{4}$ data were reported and were seriously biased by an As interference (Stauffer, 1980a, b).

The present paper reports chemical studies of $\mathrm{O}_{2}$, $\mathrm{S}(-\mathrm{II}), \mathrm{Al}, \mathrm{Fe}, \mathrm{Mn}, \mathrm{As}, \mathrm{P}$, and $\mathrm{Li}$ in two hot-spring drainages in the Lower Geyser Basin; two warm-spring drainages in the Yellowstone Canyon, and the Madison River system above Hebgen Dam. The differential effects on the solutes of temperature, $\mathrm{pH}$, and redox changes accompanying adiabatic cooling and source water mixing are examined using the conservation of mass principle and employing statistical contrast with $\mathrm{Cl}$ as the prominent conservative geothermal tracer. Our use of ratio estimation involving $\mathrm{Cl}$ as a tracer follows the early initiatives of Ellis and Wilson (1960). The intensively studied thermal drainageways are also compared chemically with representative springs sampled in the Upper, Norris, and Mammoth thermal basins.

\section{ACKNOWLEDGMENTS}

The cooperation of the U.S. National Park Service in facilitating the sampling program for this study is gratefully acknowledged. The authors thank A. H. Truesdell for his help in collecting a set of samples in 1973 and for many fruitful discussions with him; and J. M. Burchard and D.K. Nordstrom for assistance in sample collection and onsite analyses. Fluoride data were provided by $D$. K. Nordstrom. The authors acknowledge J. M. Thompson for analytical assistance and for his generous contribution of river samples for As comparisons, and John Hem and R.O. Fournier for helpful discussions.

\section{SAMPLE SOURCES}

\section{LOWER GEYSER BASIN}

The most intensive geochemical studies on hotspring drainages were on Octopus Spring (Marler, 1973, p. 435), in the lower White Creek area, and Azure Spring (Marler, 1973, p. 574), in the River Group (Fig. 1).

Octopus Spring, with its long ( $\sim 50 \mathrm{~m})$ distinct drainage channel, relatively constant flow regime, easy accessibility, and luxuriant microbiological flora, is one of several sites in the lower White Creek area where the ecology of thermophilic blue-green algae and associated bacteria has been intensively studied by T. D. Brock and coworkers (Brock, 1967, 1969; Brock and Brock, 1966, 1967, 1968a, b, 1969a, b; Walter and others, 1972).

Azure Spring has a well-developed drainage channel $\sim 100 \mathrm{~m}$ in length discharging westward into the Firehole River. The hotter satellite pool on the southwest edge of Azure Spring's main pool was also sampled. Azure is one of a large number of springs in the River Group on which major chemical constituents have been determined (Thompson and others, 1975).

Sampling stations along the two drainageways were selected to correspond to $\sim 10^{\circ} \mathrm{C}$ intervals in water temperature.

\section{YELLOWSTONE CANYON}

An unnamed sulfide-bearing spring was studied, which is 20 to $30 \mathrm{~m}$ vertically above the west bank of 


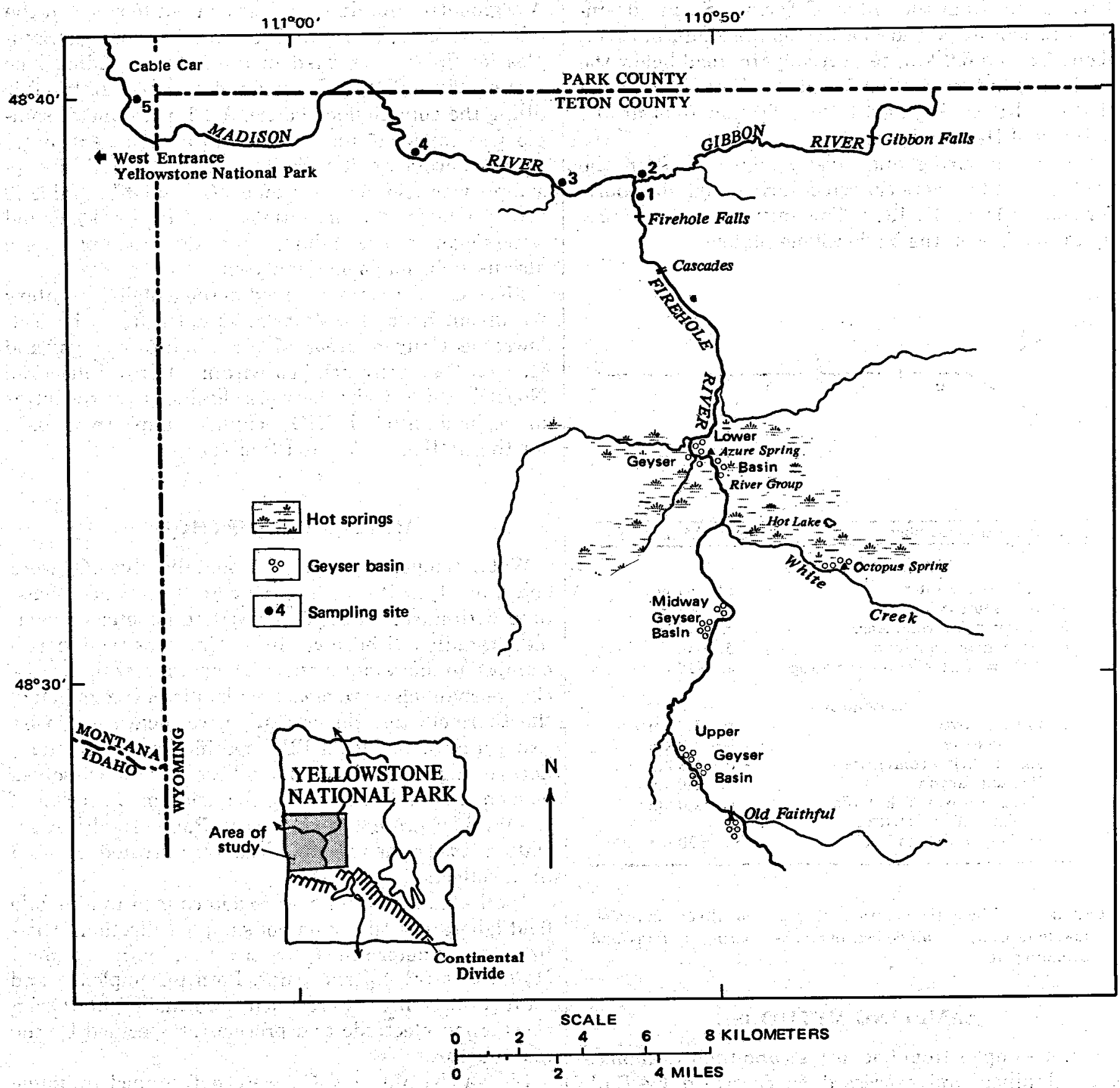

Figure 1.-Sketch map showing rivers and major hydrothermal areas sampled in Yellowstone National Park, Wyo.

the Yellowstone River, about $0.5 \mathrm{~km}$ south of Tower Falls. About $5 \mathrm{~m}$ below its source in a hillside fissure, the spring water $\left(46^{\circ} \mathrm{C}\right)$ mixes with water from a cooler $\left(14^{\circ} \mathrm{C}\right.$ ) spring (fig. 2 ). Below the confluence the mixed water runs steeply downslope until it encounters a relatively flat, poorly drained area, 5 to $10 \mathrm{~m}$ above the Yellowstone River. Samples were taken in both tributary spring drainages about $1 \mathrm{~m}$ above the confluence, immediately below the confluence, at the bottom of a small riffle, at the base of the steeply dropping combined drainage section, and at a point intermediate between the confluence and the base. Below station 5 the drainage into the Yellowstone River was indistinct.

\section{MADISON RIVER SYSTEM}

Stations 1 and 2 are on the Firehole and Gibbon Rivers, respectively, each about $1 \mathrm{~km}$ above their confluence forming the Madison River. Station 2 is 
downstream from the entry of Terrace Spring drainage. Stations 3 and 4 are located on the Madison River, about 1.8 and $6.0 \mathrm{~km}$, respectively, by road below the confluence (fig. 2). Station 5 is at the West Yellowstone Madison River Gaging Station. Station 6 is at the spillway of Hebgen Dam.

All of the spring and river samples used in the drainage studies were collected during daylight hours, September 18 to 27, 1974. The entire period was precipitation free on the Yellowstone plateau.

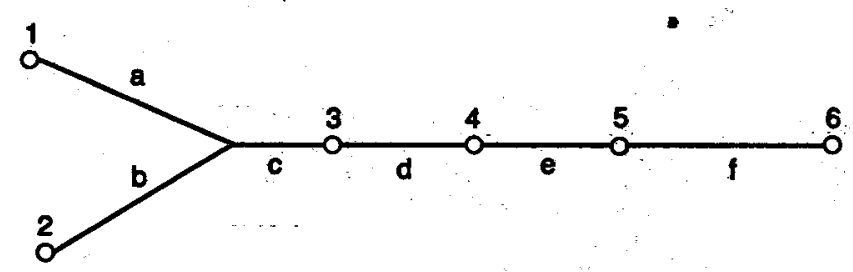

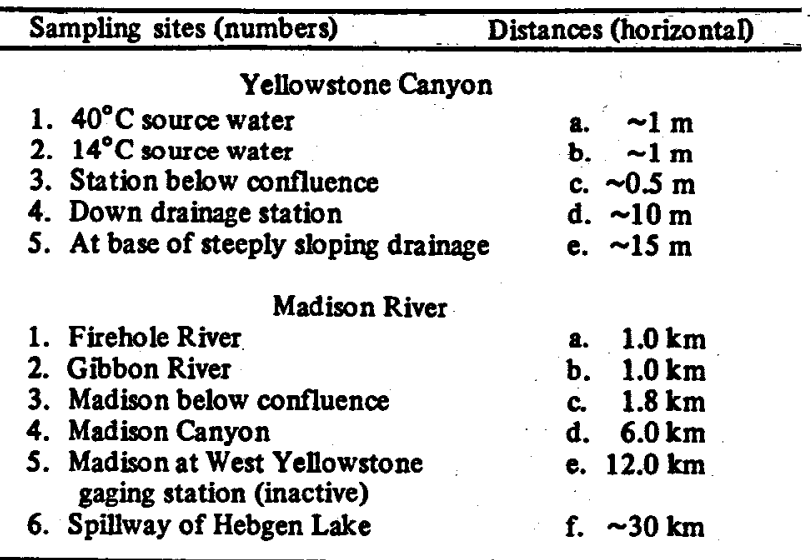

FIGURE 2.-Schematic diagram of Madison River and Yellowstone Canyon sulfide-bearing mixed spring systems and sampling sites.

\section{SAMPLING METHODS}

Water samples from hot springs and their drainages were obtained and processed as described by Ball, Jenne, and Burchard (1976). Briefly, the samples were obtained with a Masterflex ${ }^{2}$ portable electric pump equipped with silicone tubing. Filtered samples were obtained by attaching a barrel-less pressure filter assembly (142 mm diameter, $0.1 \mu \mathrm{m}$ pore size) to the silicone outflow tube of the pump (Kennedy and others, 1976). This arrangement allowed sample collection from boiling hot springs without air contacting the sample, and with a maximum temperature drop of $2^{\circ} \mathrm{C}$.

Mention of brand names is for the convenience of the reader and does not constitute endorsement by the U.S. Geological Survey.
A segmented aluminum pole was used to suspend the inlet tube over, and into, the large hot springs. Samples for S(-II) were fixed in the field by adding zinc acetate $(50 \mathrm{mg} / 250 \mathrm{~mL}$ of sample) immediately after filling the polyethylene bottle. A 1 L trace-metal sample was collected and acidified to a $\mathrm{pH}$ of 1.0 to 1.3 using concentrated redistilled $\mathrm{HNO}_{3}$. Another subsample was acidified with concentrated $\mathrm{HCl}(1 \mathrm{~mL} / 250$ $\mathrm{mL}$ sample) for determination of As (III), As (V), P, and some major cations. Filtered-unacidified samples were also used for major ion analyses.

Most samples were acidified in the mobile laboratory within an hour of collection; samples from the Yellowstone Canyon area, Mammoth hot springs, and Hebgen Dam were acidifed within $10 \mathrm{hr}$ of collection. No HCl-acidified samples were obtained from the latter areas; hence filtered $\mathrm{HNO}_{3}$-acidified samples were used for the $\mathrm{As}(\mathrm{III}), \mathrm{As}(\mathrm{V})$, and $\mathrm{P}$ analyses.

\section{ANALYTICAL METHODS}

Water temperature, $\mathrm{pH}, \mathrm{Eh}$, and dissolved $\mathrm{O}_{2}$ were determined onsite. Spring temperatures were measured with a calibrated mercury thermometer on samples rapidly withdrawn in a Thermos-type bottle clamped to the sampling pole. Temperatures in the discharge channels were measured by direct immersion of the thermometer. $\mathrm{Eh}$ and $\mathrm{pH}$ were measured onsite using a Sargent Model PBX specific ion meter and a flow-through cell (Ball and others, 1976). Dissolved oxygen was measured using the azide modification of the Winkler procedure (American Public Health Association, 1971); the fixed samples were titrated within 3 hr of collection.

Total alkalinity and $\mathrm{F}$ were determined in a mobile field laboratory on the day of sample collection. Alkalinity was determined by titration with standard $\mathrm{H}_{2} \mathrm{SO}_{4}$ to a $\mathrm{pH} 4.5$ end point. Both uncomplexed and total F activities were measured using an Orion specific ion electrode and procedures specified by the manufacturer.

$\mathrm{Li}, \mathrm{Na}, \mathrm{K}, \mathrm{Mg}$, and $\mathrm{Ca}$ were determined by flame atomic absorption using a Perkin Elmer Model 303 or 306 spectrophotometer, following procedures issued by the manufacturer. $\mathrm{SiO}_{2}$ was analyzed by direct current plasma spectroscopy using a Spectrospan III operating in single element mode.

$\mathrm{Cl}$ and $\mathrm{SO}_{4}$ were determined by cation exchange using a refinement (Stauffer, 1980b) of the method of Mackereth (1963). The refinement was necessary to cope with the high F levels in Yellowstone Park thermal waters. P, As(III), and As(V) were determined following an adaptation (Stauffer, 1980b) of the molybdate procedure of Johnson and Pilson (1972a). 
$\mathrm{Fe}, \mathrm{Mn}$, and $\mathrm{Al}$ were determined using flame atomic absorption spectrometry, following 8-quinolinol MIBK extractions. Al was also extracted from filtered, unacidified, cooled water samples on the day of sampling following the procedure of Kennedy, Zellweger, and Jones (1974). Field-extracted Al (back extracted from MIBK into 1.0 molar $\mathrm{HNO}_{3}$ ) was subsequently analyzed by flame atomic absorption.

Total dissolved $\mathrm{Sb}$ was analyzed using a modification (Stauffer, 1977) of the Yanagisawa, Takeuchi, and Suzuku (1973) atomic absorption procedure.

Total dissolved S(-II) was determined on fixed samples using the potentiometric procedure of Baumann (1974).

\section{RESULTS}

\section{DATA RELIABILITY}

\section{PURE ANALYTICAL ERROR}

Identification of chemical processes acting in the hot-spring drainages depends in part on the magnitude of the analytical errors. Estimates of the analytical coefficients of variation (c.v.) for pertinent solute levels and the most important solute species are contained in table 1 . The errors (table 1) apply to individual variates; the variance of the mean $\bar{X}$ of $n$ independent identically distributed (statistically) $X$ values is given by equation 1 (Hogg and Craig, 1970):

$$
\operatorname{Var} \bar{X}=\operatorname{Var} X / n \text {. }
$$

The mean square errors (squared bias plus variance) for $\mathrm{K}$ and $\mathrm{Li}$ are the smallest. The low levels of $\mathrm{Ca}$ and particularly $\mathrm{Mg}$ in the "typical" alkaline Upper or Lower Basin hot springs imply large analytical coefficients of variation.

In general, the low levels of $\mathrm{SO}_{4}$ and high concentrations of $F$ in the Upper and Lower Basins result (table 2) in significant potential biases in $\mathrm{SO}_{4}$ estimates obtained using the cation-exhange method. The problem is ameliorated considerably in the river waters, and in hot-spring waters from north of Madison Junction, because of large associated increases in the $\mathrm{SO}_{4} / \mathrm{F}$ molar ratio (Rowe and others, 1973; Thompson and others, 1975). Because of the dominance of $\mathrm{Cl}$ in most of the waters being considered here, the $\mathrm{Cl}$ data has a c.v. of 1 percent, about equal to that for data published elsewhere on these waters (Rowe and others, 1973; Thompson and others, 1975).

Errors associated with the As and $\mathrm{P}$ species are discussed in detail elsewhere (Stauffer, 1980a, b). The P levels in the typical alkaline hot-spring waters are
TABLE 1.-Analytical precision of solute data

\begin{tabular}{|c|c|c|c|}
\hline Solute & $\begin{array}{l}\text { Analytical } \\
\text { method* }\end{array} \cdots \quad \cdots \quad \begin{array}{l}\text { Level } \\
\text { (mg } / \mathrm{L})\end{array}$ & $\begin{array}{l}\text { Coefficient } \\
\text { of variation*** } \\
\text { (c.v.) (percent) }\end{array}$ & Remarks \\
\hline 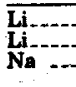 & $\begin{array}{ll}\text { Flame AA } & 0.50 \\
\text { Flame } & \mathbf{A A} \\
330 & 100\end{array}$ & $\begin{array}{l}0.3-0.5 \\
.3-.5 \\
.5\end{array}$ & \multirow{2}{*}{$\begin{array}{l}\text { C.v. insensitive to } \\
\text { level. } \\
\text { c.v. becomes progres- } \\
\text { sively worse for levels } \\
\text { under } 100 \mathrm{mg} / \mathrm{L} \\
\text { Probably most sensi- } \\
\text { tive method. }\end{array}$} \\
\hline$\underset{\mathbf{K}}{\mathrm{Na}}$ & Flame AA & $\begin{array}{ll}2-3 \\
.2-3\end{array}$ & \\
\hline $\begin{array}{l}\mathrm{Mg} \\
\mathbf{M g} \\
\mathbf{C a} \\
\mathrm{Ca} \\
\mathrm{Cl}\end{array}$ & $\begin{array}{cc}\text { do } & 1.1 \\
\text { do- } & 1.0 \\
\text { Conductivity, } & 60 \\
\text { cation exchange. } & \end{array}$ & $\begin{array}{l}3.6 \\
2.0 \\
2.5 \\
1.0 \\
1.0\end{array}$ & \multirow[t]{3}{*}{ 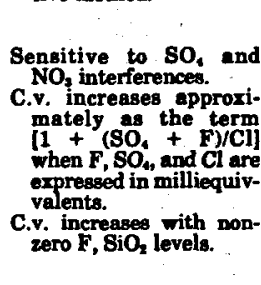 } \\
\hline 0, & 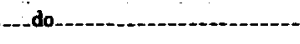 & -2.0 & \\
\hline 列 & Specific ion & 2.0 & \\
\hline $\begin{array}{l}\text { Alka- } \\
\text { linity }\end{array}$ & $\begin{array}{l}\text { eletrode. } \\
\text { Titration }\end{array}$ & 1.0 & \multirow{3}{*}{$\begin{array}{l}\text { Noncarbonate alkalinity } \\
\text { may be }>25 \text { percent of } \\
\text { total. } \\
\text { c.v. increases with de- } \\
\text { creasing level, sensi- } \\
\text { tive to Po, at low level. }\end{array}$} \\
\hline As & pectrophotometric & 2.0 & \\
\hline As $=$ & $\begin{array}{lr} & 2.00 \\
\text { Flame AA, wolvent } & .10\end{array}$ & 8.3 & \\
\hline & do & 12.0 & \multirow{6}{*}{$\begin{array}{l}\text { Recovery dependent upon } \\
\text { volume colvent extrac- } \\
\text { ted. }\end{array}$} \\
\hline $\mathrm{Sb}$ & Flame AA, lab & 4.0 & \\
\hline & dame AA, lab & 2.0 & \\
\hline & $\begin{array}{l}\text { solvent extracted. } \\
\text { Flame AA, lab }\end{array}$ & $\begin{array}{l}2 \\
1.5\end{array}$ & \\
\hline $\begin{array}{l}\mathrm{Fe} \\
\mathrm{O}_{2}(\mathrm{~s} \\
\mathrm{S}^{-2}\end{array}$ & 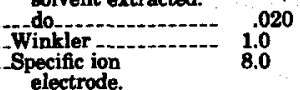 & $\begin{array}{l}2.5 \\
5.0 \\
1.0\end{array}$ & \\
\hline $\mathbf{S}^{-2}$ & 3.0 & 3.0 & \\
\hline
\end{tabular}

- AA = Atomic absorption.

- Coefficient of variation (c.v.) $=100 s_{x} \sqrt{I}$ when $s_{x}$ is the estimated standard pure analytical error for an individual replicate.

near the detection limit of $\sim 2 \mu \mathrm{g} / \mathrm{L}$. At these low levels the $\mathbf{P}$ estimates are also positively biased by the very large concentrations of $\mathrm{SiO}_{2}$ invariably present in geothermal waters. The relative root-mean-square errors and c.v. for total As are among the smallest for any of the solutes analyzed in these hot-spring waters. Both the accuracy and precision of the total As components, $A s(I I I)$ and $A s(V)$, suffer, however, from uncertainties in the preservation of $\mathrm{As}$ (III) at the time of sampling of the boiling hot-spring waters, as well as methodological constraints associated with molybdenum-blue (Stauffer, 1980a, b).

The precision of the total $F$ data decreases at the low concentrations found in high-Ca waters in Yellowstone Canyon.

The c.v. for $\mathrm{S}(-\mathrm{II})$ is likely to be small compared with $\mathrm{ZnS}$ oxidation biases which may have resulted from 3 months of storage of the samples prior to analysis. Possible oxidation effects (resulting in negative biases) were not evaluated. However, Brock, Brock, Bott, and Edwards (1971), citing thesis work of Pachmayr, state that the $\mathrm{ZnS}$ precipitates are stable against oxidation for weeks. The sulfide data reported here are likely to be minimum values. 
TABLE 2.-Chemical and physicial parameters of Octopus Spring and its drainage [Temperature, $\mathrm{Eh}, \mathrm{pH}$, and $\mathrm{O}_{2}$ are field determinations; other analyses performed after return to Menlo Park Laboratory, except as noted]

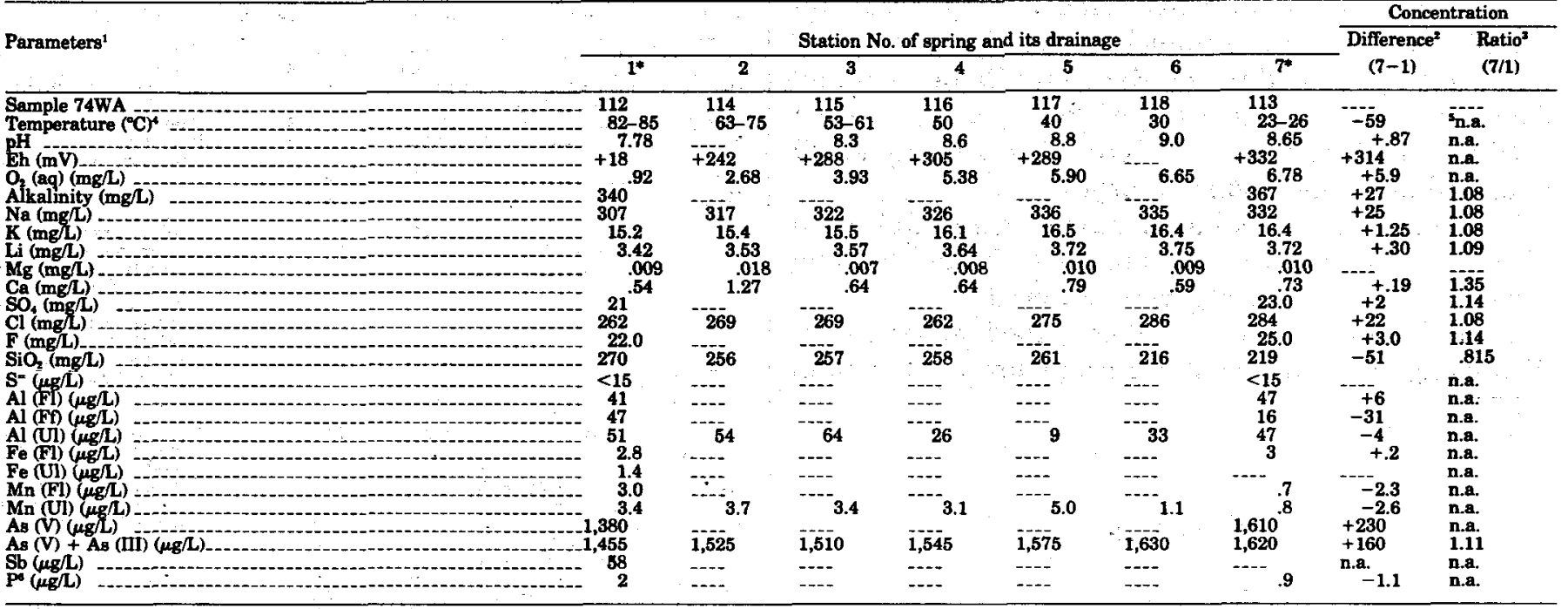

*Filtered samples, except as noted. Stations 2-6 were unfiltered; $U 1$ = unfiltered and lab extracted. 2 Concentration at station 7 minus that at station 1 .

3Concentration ratio of station 7 to station 1.

Temperature variations in response to discharge periodicity was measured at selected stations only.

Not applicable.

Soluble reactive phosphorus as P (Strickland and Parsons, 1968;.

The alkalinity data were adjusted for partial protonation of $F$ (Ellis, 1963) and incomplete protonation of $\mathrm{HCO}_{3}$ at the $\mathrm{pH}=4.5$ alkalinity end point. Corrections for the protonation of dissolved borates and silicates were not made. However, the protonation of dissolved silicates may introduce an error in some instances (D. V. Vivit and others, unpub. data, 1978).

Among the solvent-extracted elements quantified by atomic absorption ( $\mathrm{Al}, \mathrm{Mn}, \mathrm{Fe}$, and $\mathrm{Sb}$ ), $\mathrm{Al}$ and $\mathrm{Sb}$ suffer from the largest analytical variances. Low levels of $\mathrm{Al}$ tax the sensitivity constraints on $\mathrm{Al}$ analysis by flame; flameless atomic absorption for $\mathrm{Al}$ is inherently imprecise. Furthermore, the field extractions of $\mathrm{Al}$ have error components resulting fom the following factors: (1) Field constraints prevented extracting the samples immediately after sampling; in fact, the time lag varied from 1 to $24 \mathrm{hr}$; (2) the solution temperature during the extraction procedure varied from about $6^{\circ}$ to $50^{\circ} \mathrm{C}$, with possible effects on solvent-extraction efficiency. The $\mathrm{Sb}$ procedure is influenced by $\mathrm{SiO}_{2}$ levels; the high and variable levels of $\mathrm{SiO}_{2}$ in the hot-spring waters and the very complex polymerization chemistry of $\mathrm{SiO}_{2}$ contribute the major analytical component of variance to the $\mathrm{Sb}$ analyses (Stauffer, 1977).

\section{SAMPLING ERRORS}

Although physical-chemical conditions in the springs are relatively invariant, the estimated concen- trations of solutes at fixed points along the down drainages vary (time scale $=$ minutes) with spring discharge. The channel-water temperatures are positively correlated with discharge, and evaporative cooling results in a concentration of solutes in the remaining liquid phase. From the Bowen equation (Bowen, 1926) it can be shown that 95 percent of the heat dissipation of $85^{\circ} \mathrm{C}$ (spring orifice temperatures) and 88 percent of the heat dissipation at $50^{\circ} \mathrm{C}$ is evaporative (latent heat transfer). A latent heat transfer model implies a 0.18 to 0.19 percent increase in conservative solute concentration for each $1^{\circ} \mathrm{C}$ of evaporative cooling. The sun's radiant heat input may approximate $15 \mathrm{cal} / \mathrm{g}$ water. A purely latent heat transfer model approximates total water losses through evaporation in the channel. Thus, the small amount of sensible heat exchange is approximately balanced by dissipation of the added radiant energy.

Drainage stations could not be synoptically sampled; thus variable spring discharge introduces a withinstation and a between-station component of sampling variance to the estimated solute concentrations. Based on the coefficient 0.19 , and the observed short-term temperature variations in the Lower Basin drainages studied (tables 2, 3), the "sampling"' component (c.v.) of solute concentration errors is $\sim 1.0$ percent, a value larger than the analytical "pure error" for the major alkali ions but $\leqslant$ analytical c.v.'s for the major anions (table 1). The analytical and sampling errors should be 
TABLE 3.-Chemical and physical parameters of Azure Spring and its drainage [Temperature, Eh, pH, and $\mathrm{O}_{2}$ are field determinations; other analysees performed after return to Menlo Park laboratory, except as noted.]

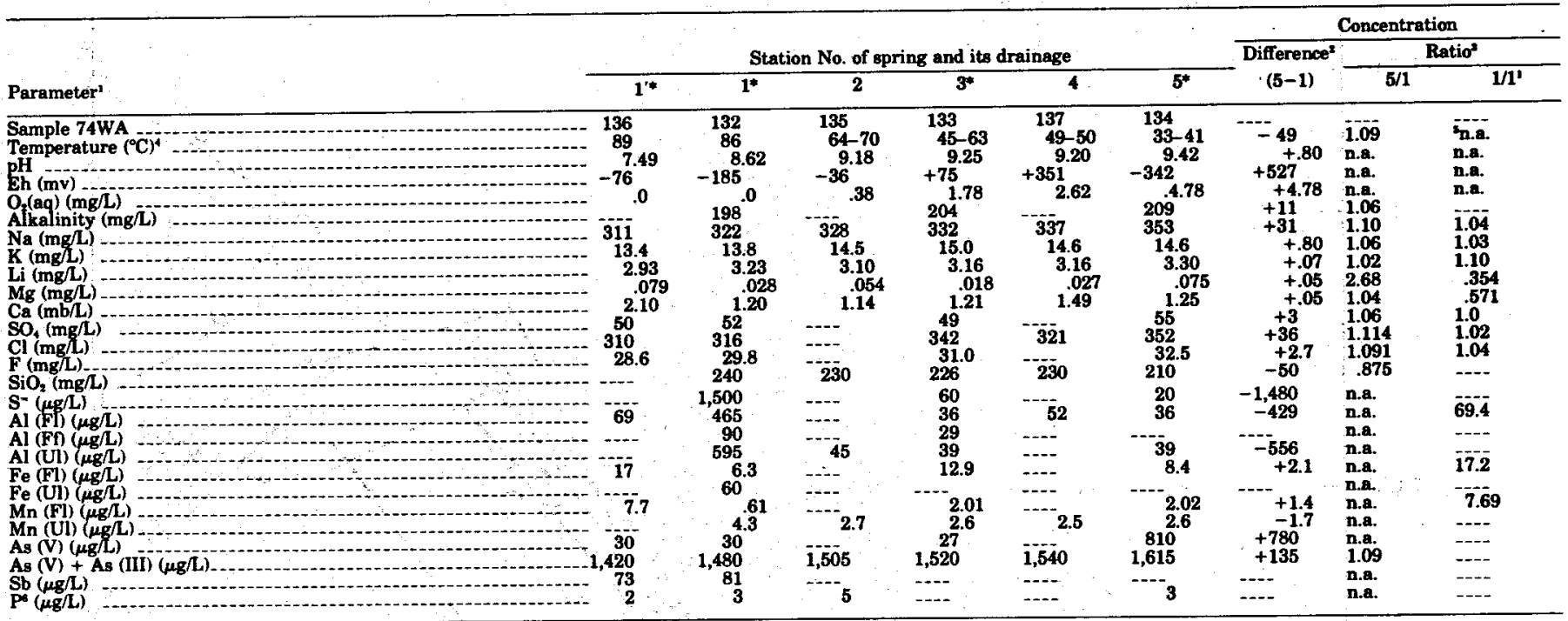

* Filtered samples, except as noted. Stations 2 and 4 were unfiltered.

IFf $=$ Filtered and field extracted; $\mathrm{Fl}=$ filtered and lab extracted; $\mathrm{Ul}$ = unfiltered and lab extracted. 2Concentration at station 5 minus that at station 1 .

Temperature variation in response to discharge periodicity was measured at selected stations only. sNot applicable.

SNot applicable.
Soluble reactive phosphorus as P (Strickland and Parsons, 1968.)

independent (hence additive) in reckoning the total uncertainty in solute concentration at any point along the drainage channel.

\section{STATISTICAL DEFINITIONS}

Let $R(S)_{i j}$ be the ratio $R$ of concentration for solute $S$ at stations $i$ and $j$, respectively, along a drainage channel. Let $R_{i}(S)$ be the ratio where the base station $j=1$. For mixed water systems, let $P_{i}(S)$ denote the fraction of water at station $i$ which is contributed by source 1 calculated (equation 2) using the conservation of mass principle for solute $S$ (equation 3 ):

$$
\begin{aligned}
& P_{i}(S)=\left(C_{i}-C_{2}\right) /\left(C_{1}-C_{2}\right) \\
& P^{*} C_{1}+(1-p)^{*} C_{2}=C_{1},
\end{aligned}
$$

where $C$ denotes the concentration of solute $S$, and $p$ is the mixing fraction.

\section{OCTOPUS AND AZURE SPRINGS}

\section{OXIDATION AND DIFFUSION PROCESSES}

Several oxidative and diffusion-controlled processes have been identified in these two Lower Geyser Basin hot-spring drainages (figs. 3 and 4). Oxygen concentration and Eh increase with station number because of oxygen diffusion from the atmosphere into the cooling turbulent flow; $\mathrm{pH}$ increases 1 to 2 units, presumably
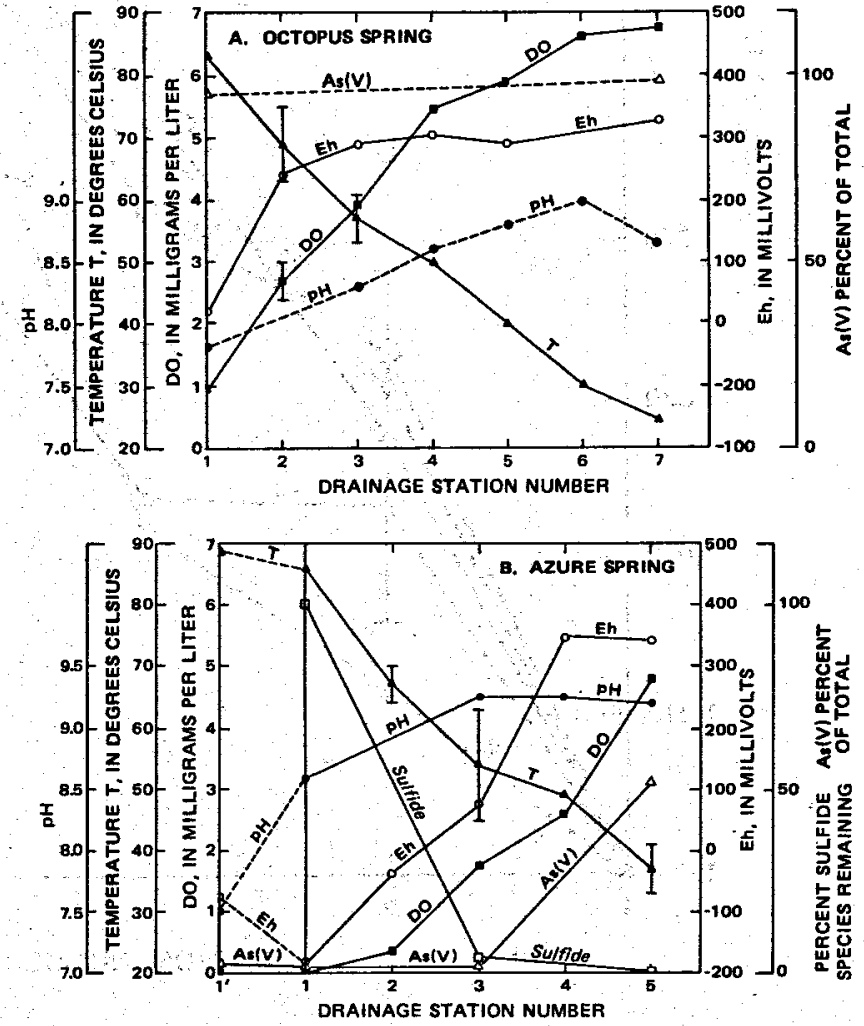

Figure 3.-Physical and chemical parameters of two hot springs and their drainages. (Vertical bars on curves represent the range in observed values. Sulfide was below detection in Octopus Spring.) 


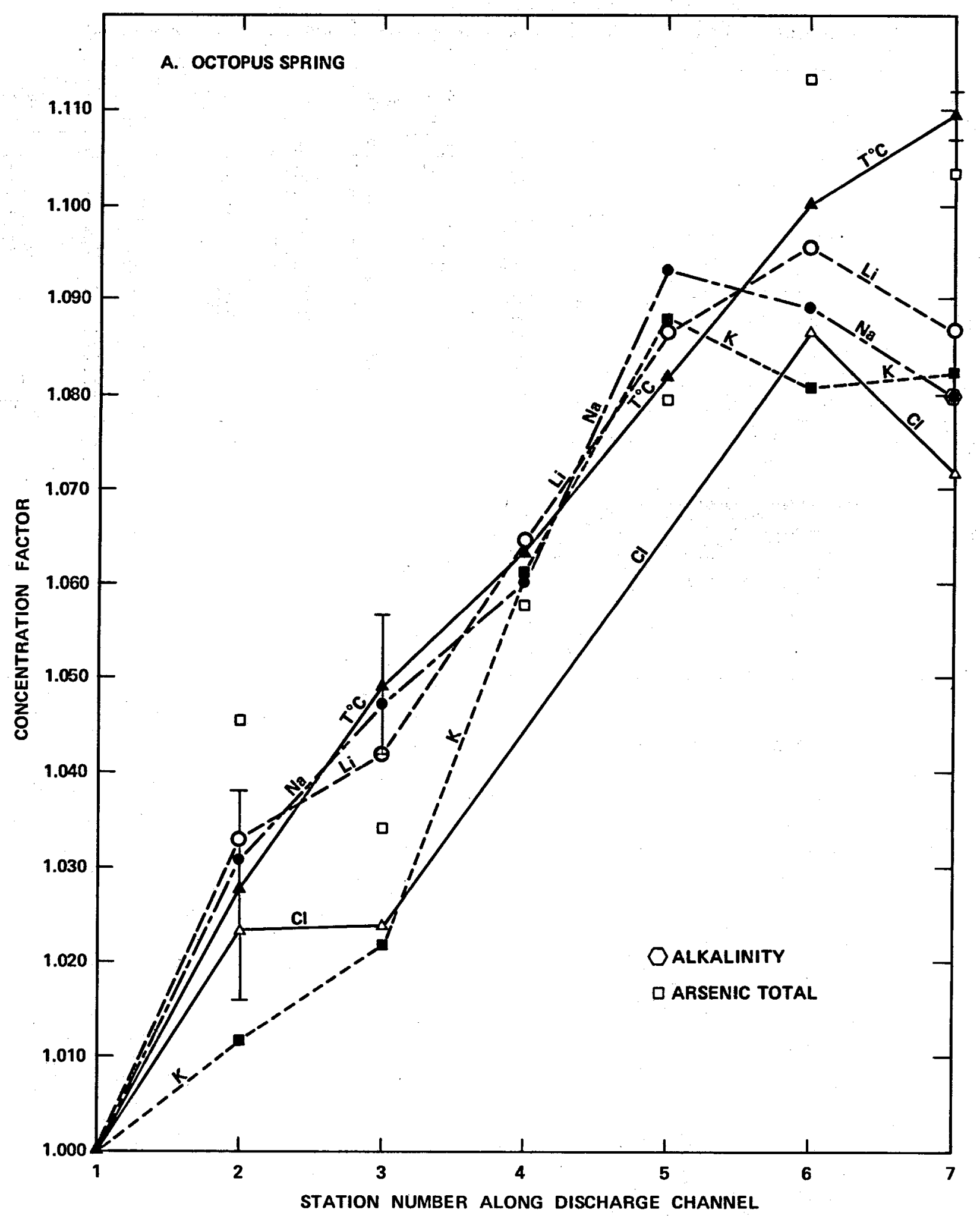

Figure 4.-Concentration factors of several parameters for two hot springs and their drainages. (The vertical bars on the $T$ curves represent limits on the concentration factors which are attributed to the observed temperature range. The concentration factors for the satellite pool in figure $4 B$ are inverted to economize on graphical representation).

because of $\mathrm{CO}_{2}$ losses accompanying evaporative cool- fluctuations because gaseous diffusion is sensitively reing. Analytical dissolved $\mathrm{O}_{2}$ concentrations in the upper channels are particularly sensitive to discharge lated to water temperatures, turbulence, and residence time in the channel. 


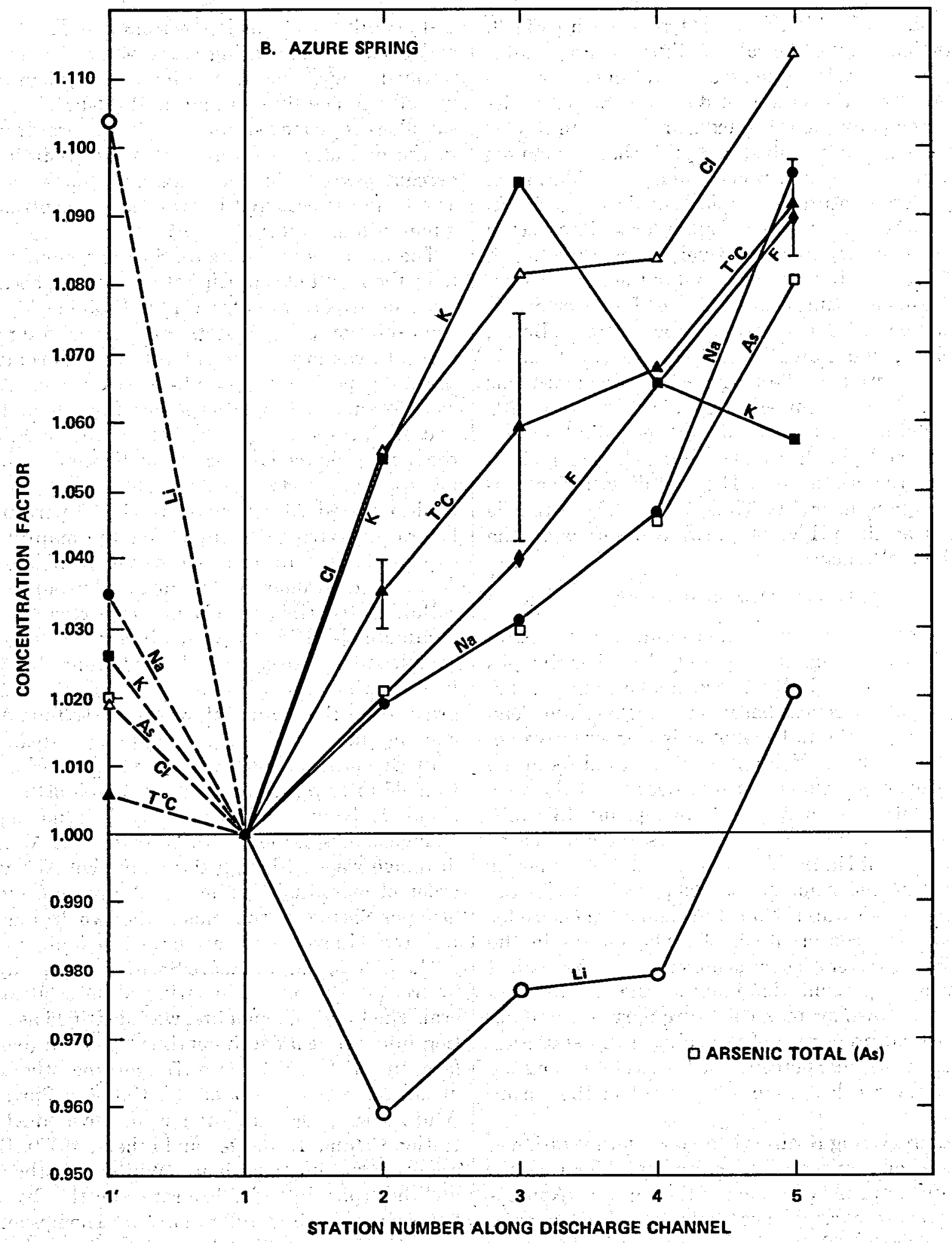

Figure 4.-Continued.

If dissolved $\mathrm{O}_{2}$ is detectable by Winkler titration, $\mathrm{S}(-\mathrm{II})$ is below detection, Eh is positive, and the $\mathrm{As}$ (III)/As(V) ratio is much less than 1 (figs. 3,4 ). Conversely, the presence of analytically detectable $\mathrm{S}(-\mathrm{II})$ implies near-zero dissolved $\mathrm{O}_{2}$ levels, negative Eh values, and large $\mathrm{As}(\mathrm{III}) / \mathrm{As}(\mathrm{V})$ ratios (in some cases $>50$ ). Arsenite (As(III) ) is not oxidized in significant quantities until after the $\mathrm{S}(-\mathrm{II})$ has been either volatilized 
or oxidized. The $\mathrm{S}(-\mathrm{II})$-dissolved $\mathrm{O}_{2}$ relationship (fig. 3) suggests that at $90^{\circ} \mathrm{C}$ the rate of diffusion of molecular $\mathrm{O}_{2}$ into the hot pools is the rate-controlling step in the oxidation of $\mathrm{S}(-\mathrm{II})$. Traces of dissolved $\mathrm{S}(-\mathrm{II})$ sometimes accompany nonzero oxygen levels in cooler down-drainage water (tables 2,3); this thermodynamic disequilibrium probably reflects delayed oxidation at the lower temperature. The abiotic oxidation of $\mathrm{S}(-\mathrm{II})$ is known to be approximately first order with respect to both $\mathrm{S}(-\mathrm{II})$ and $\mathrm{O}_{2}$, to be relatively insensitive to $\mathrm{pH}$, and to be relatively slow compared to the expected hydraulic residence times (minutes) in the lower drainage channels (O'Brien and Birkner, 1977). Brock, Brock, Bott, and Edwards (1971) noted that sulfur bacteria are active in oxidizing $\mathrm{S}(-\mathrm{II})$ (using molecular $\mathrm{O}_{2}$ ) even at boiling temperatures (approximately $92^{\circ} \mathrm{C}$ on the Yellowstone plateau) in the alkaline hot springs. Some $\mathrm{H}_{2} \mathrm{~S}$ volatilizes from the channels, yielding the characteristic odor. The first dissociation constant of $\mathrm{H}_{2} \mathrm{~S}$ is near 7.0. Thus, $\mathrm{H}_{2} \mathrm{~S}$ volatilization is decreased at the $\mathrm{pH}$ values near 8 observed in the lower channel reaches.

\section{PRECIPITATION REACTION}

The hypothesized evaporation-solute concentration model ( $T$ curves in fig. 4) adequately describes changes in $\mathrm{F}, \mathrm{Cl}, \mathrm{As}$, and $\mathrm{Na}$ in the two drainage channels (fig. 4). Statistical inferences based on the $R(S)$ ratios lead to acceptance of the null hypothesis (conservative behavior) for $\mathrm{Na}, \mathrm{K}, \mathrm{Li}, \mathrm{F}$, alkalinity, and total As in the downdrainage of Octopus Spring. Because of the very high concentrations of $\mathrm{Na}$ in Azure Spring (13.5 millimolar) relative to other constituents, the anticipated low reactivity of $\mathrm{Na}$ in this situation, and the superior analytical precision for $\mathrm{Na}$ as compared to $\mathrm{Cl}$ in the high-SO ${ }_{4}$, high-F water, $\mathrm{Na}$ is the element of choice for evaluating the conservatism of other solutes in the Azure Spring system. There is no convincing statistical evidence of As precipitation in either the satellite pool or along the down drainage of Azure Spring. Applying the statistical properties of the solute ratio statistics, with probability $\sim 95$ percent, the losses of As along the drainageway are less than 1.8 percent of the spring flux.

The Azure Spring K ratios increase prior to station 4, as expected of a conservative solute, and then decrease significantly in the latter part of the channel. Approximately 95-percent confidence limits on the $\mathrm{K}$ losses prior to station 5 are $3.5 \pm 0.9$ percent, or $0.48 \mathrm{mg} / \mathrm{L}$ of $\mathrm{K}$.

$\mathrm{Li}$ is nonconservative in the Azure Spring system. A 7.5 percent loss of $\mathrm{Li}$ is indicated prior to station 2 of the downdrainage and an 8 percent loss in the satellite as compared to the main upwelling pool (fig. 4). After station 2 , the $\mathrm{Li}$ ratios increase at a rate which is not statistically distinguishable from the $\mathrm{T}, \mathrm{Cl}, \mathrm{Na}, \mathrm{As}$, and $\mathrm{F}$ curves, indicating conservative behavior after initial $\mathrm{Li}$ deposition in the immediate vicinity of the upwelling. The filtered and unfiltered $\mathrm{HNO}_{3}$-acidified sample sets yielded similar results (8 percent loss of $\mathrm{Li}$ in the downdrainage, all of it prior to station $3 ; 9^{1 / 2}$ percent low concentration anomaly in the satellite). The Li losses occurred in two sharply contrasting regimes of temperature and $\mathrm{pH}$.

The Li losses in the Azure Spring system are likely to be the result of coprecipitation with $\mathrm{Al}$, because $\mathbf{4 3 0}$ $\mu \mathrm{g} / \mathrm{L}$, or 92 percent of the original soluble $\mathrm{Al}$, was lost from solution prior to station 3 and $>395 \mu \mathrm{g} / \mathrm{L}$, or 85 percent, was lost in the satellite pool as compared to the main pool. Total (solute + suspended) Al losses were 525 and $555 \mu \mathrm{g} / \mathrm{L}$ in the satellite pool and prior to station 3, respectively. The field-extracted $\mathrm{Al}$ data for the main pool and channel show the same trend as the laboratory-extracted $\mathrm{Al}$ data (table 3); however, the field-extracted $\mathrm{Al}$ estimate is only 19 percent of the laboratory-extracted estimate for the main pool. One explanation for this contrast is that the field-extracted Al (filtered through a $0.1 \mu \mathrm{m}$ membrane) includes a colloidal fraction which is not extractable with 8-quinolinol-MIBK but which becomes soluble during sample storage at $\mathrm{pH} \simeq 1$. The difference between the field- and laboratory-extracted soluble $\mathrm{Al}$ estimate is greatest for the main pool, where the soluble $\mathrm{Al}$ is presumably in the process of being precipitated.

In Octopus Spring the field-extracted $\mathrm{Al}$ decreases from 47 to $16 \mu \mathrm{g} / \mathrm{L}$, concomitant with a $\mathrm{pH}$ increase of about 1 , between stations 1 and 7 ; no significant change occurs in the laboratory-extracted $\mathrm{Al}$ along the drainage way. Although the main pool Al level is an order of magnitude higher for Azure as compared to Octopus Spring, at the ends of the two drainage channels the $\mathrm{Al}$ levels have converged to similar values.

The Li losses in the Azure Spring system may be due to precipitation of a Li-bearing aluminosilicate mineral. The Li mica, lepidolite, was identified as a deposition mineral at a depth depth of 25-40 m (below surface) in the Y-3 drill core (Barger and others, 1973), about $75 \mathrm{~m}$ northwest of Ojo Caliente Spring. Like Azure Spring, Ojo Caliente has an elevated Al concentration $(1.0 \mathrm{mg} / \mathrm{L}$, Barger and others, 1973). Both the scientific drilling experience (White and others, 1975) and the typically high $\mathrm{Cl} / \mathrm{Li}$ ratios for the River Group hot springs (R. E. Stauffer and J. M. Thompson, unpub. data, 1975) suggest that Azure Spring and Ojo Caliente are derived from a common hot-water upflow regime where $\mathrm{Li}$ is being precipitated in the epithermal zone.

If lepidolite is, in fact, forming in Azure Spring, the $\mathrm{Li}$ losses are probably not confined to the formation of this mineral. The $\mathrm{Al} / \mathrm{Li}$ molar loss ratio for Azure 
Spring is estimated to be 0.42 , in contrast to the ratio 1.27 for lepidolite found by Barger, Beeson, Fournier, and Muffler (1973). Furthermore, the stoichiometry of lepidolite $\left(\mathrm{K}_{2} \mathrm{Li}_{3} \mathrm{Al}_{3}\left(\mathrm{AlSi}_{3} \mathrm{O}_{10}\right)_{2}(\mathrm{OH} \text { F })_{4}\right)$ calls for $\mathrm{K}$ losses in the Azure Spring system twice as large as those inferred from figure 4.

The concentrations of $\mathrm{Mn}$ and $\mathrm{Fe}$ in Azure and $\mathrm{Oc}$ topus Spring waters are representative of the very low levels of these two elements in typical alkaline high-Cl $(>250 \mathrm{mg} / \mathrm{L}$ ) hot springs in the Upper, Lower and Norris Geyser Basins (tables 4 and 5). Significantly, water collected from the base of Porcelain Terrace at Norris has the lowest levels of both $\mathrm{Fe}$ and $\mathrm{Mn}$ of all the waters tested; this spring also has the highest $\mathrm{Cl}$ level, hence the minimum dilution of hot-spring water, in Yellowstone Park. Ear Spring, representative of the high-Cl, low- $\mathrm{HCO}_{3}$ waters of Geyser Hill, Upper Basin, also features low levels of both Fe and Mn. An unnamed spring north of the Old Faithful interchange is a warm spring formed by near-surface dilution of hot high-Cl water with meteoric water. By contrast, this diluted spring has relatively high levels of both $\mathrm{Fe}$ and Mn. Steady Geyser is a dilute (low-Cl) hot spring in the Lower Basin characterized by low Fe levels and a large $\mathrm{Mn} / \mathrm{Fe}$ ratio (table 5). The elevated $\mathrm{Mn} / \mathrm{Fe}$ ratio indicates preferential oxidation of $\mathrm{Fe}$ (II) and losses from solution following dilution near surface waters. Little Whirligig water is a mixture of high- $\mathrm{Cl}$, low- $\mathrm{HCO}_{3}$ Norris deep water with acid-sulfate water (low-Cl) of surficial origin. The acidic $\mathrm{pH}$ of the mixture preserves the relatively high levels of both $\mathrm{Fe}$ and $\mathrm{Mn}$ and the small $\mathrm{Mn} / \mathrm{Fe}$ ratio to be expected from leaching of country rock by the acid-sulfate water component. Brock,
TABLE 5.-Chloride, aluminum, iron, and manganese in selected geysers and hot springs

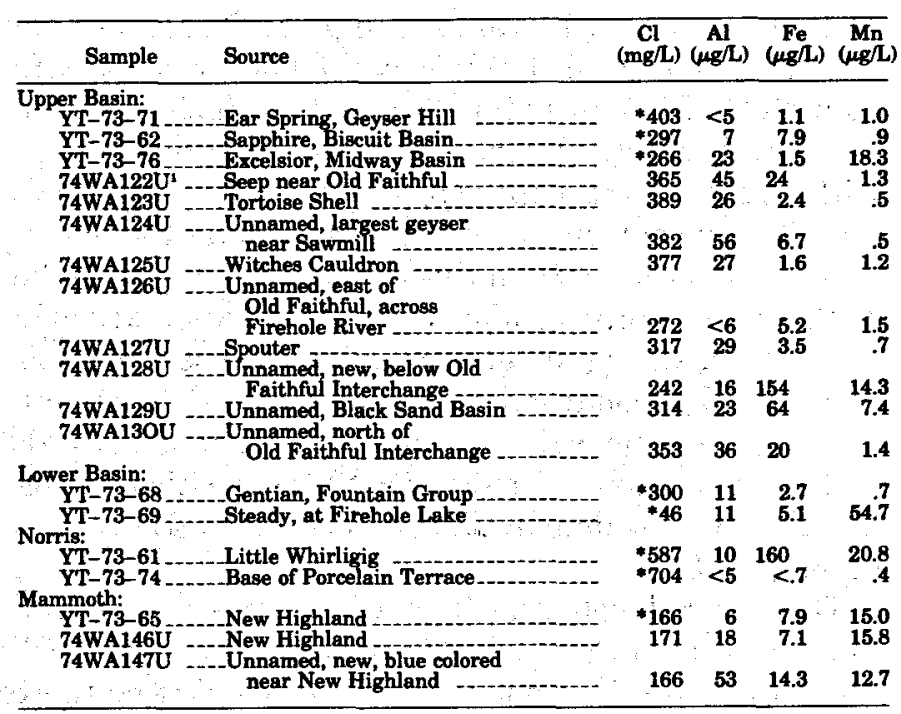

*Chloride analyses by J.M. Thompson on $\mathrm{HNO}_{3}$ acidified samples.

* Chloride analyses by J. M. Thompson on $\mathrm{HNO}_{3}$ acidified samples. samples were filtered.

Cook, Peterson, and Mosser (1976) have found pure "acid sulfate type" (White, 1957; White and others 1971) thermal waters in Gibbon Meadows and Norris Basin with total soluble Fe levels (Fe(II) and $\mathrm{Fe}$ (III)) exceeding $50 \mathrm{mg} / \mathrm{L}$.

\section{UNNAMED SULFIDE-BEARING SPRINGS IN YELLOWSTONE CANYON}

Generically, both the $46^{\circ} \mathrm{C}$ source waters in the unnamed sulfide-bearing spring system in Yellowstone Canyon would be classified as "warm" springs of

TABLE 4.-Selected physical and chemical properties of additional hot waters

[Temperature, $\mathrm{E}_{\mathrm{h}}$ and $\mathrm{O}_{2}$ are field determinations; other analyses performed after return to Menlo Park Laboratory]

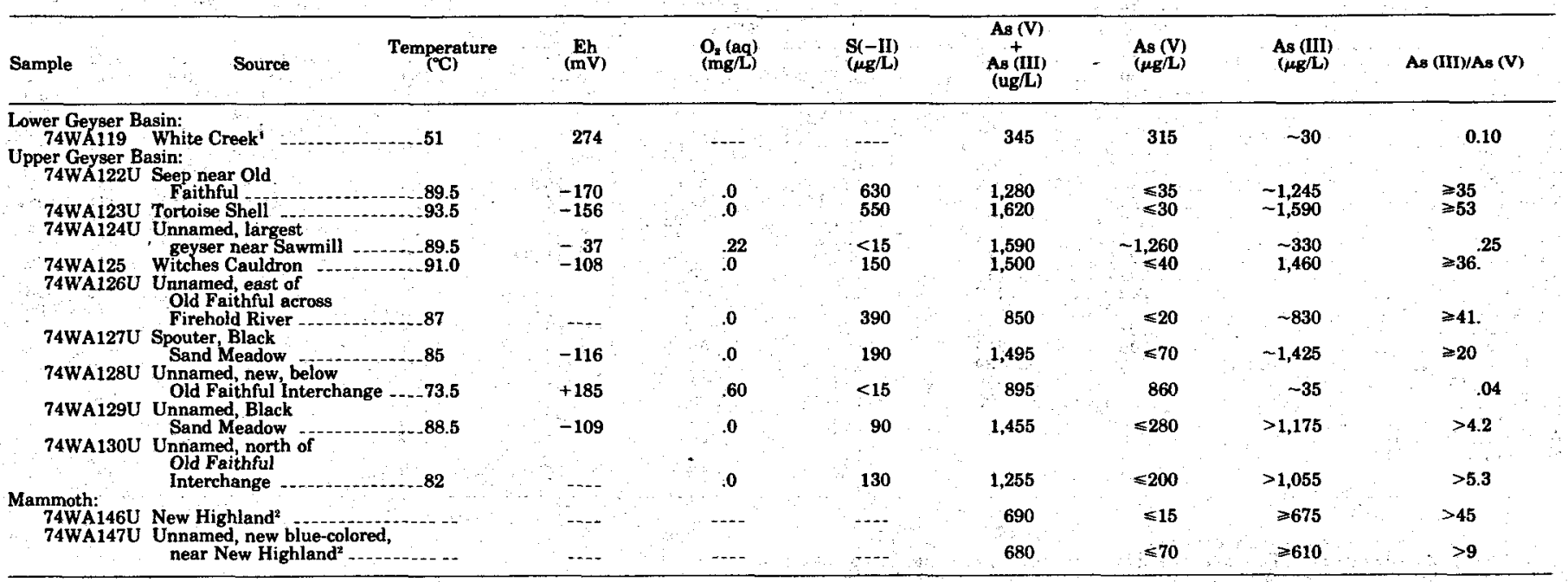

'Filtered sample; the other samples are unfiltered.

${ }_{2} \mathrm{On} \mathrm{HNO}_{3}$-acidified samples. 
"mixed" origin (see Fournier and others, 1974; Fournier and Truesdell, 1974; Fournier and others, 1976). The intermediate $\mathrm{Cl}$ levels and high $\mathrm{HCO}_{3}, \mathrm{Mg}$, and $\mathrm{Ca}$ concentrations (table 6) identify the two source waters as high-Cl, high-enthalpy deep water which has been extensively diluted by meteoric water and has reacted with underlying carbonate rock strata. The high S(-II) and $\mathrm{SO}_{4}$ concentrations of the springs, and the extensive solfataric activity in the surrounding region of the Yellowstone Canyon, may have their explanation in hot water leaching underlying sulfur-rich sedimentary rock. Similar conditions also exist in the Mammoth area, where some warm springs have reduced $\mathrm{Cl}$ levels and concentrations of major constituents which resemble the $46^{\circ} \mathrm{C}$ source water studied here (Rowe and others, 1973).

The low $\mathrm{F}$ levels and high $\mathrm{Cl} / \mathrm{F}$ ratios in the Yellowstone Canyon Springs (derived from data in table 6) probably result from fluorite equilibria acting on these high-Ca waters (Mahon, 1964; Nordstrom and Jenne, 1977).

The sharp increases in $\mathrm{pH}, \mathrm{Eh}$, and dissolved $\mathrm{O}_{2}$ concentration below the confluence and the decreases in $\mathrm{S}(-\mathrm{II})$ reflect gas exchange $\left(\mathrm{CO}_{2}, \mathrm{H}_{2} \mathrm{~S}\right)$ with the atmosphere and S(-II) oxidation, respectively. The highcarbonate alkalinity of these waters dominates the $\mathrm{pH}$ despite the release of protons accompanying S(-II) oxidation.

Inferences based on the solute mixing fraction statistics $P(S)$ (equation 3 ) must account for the solute- specific variances. The $\mathrm{Li}$ and $\mathrm{K}$ statistics are the most precise because of the large concentration differences between the two source waters for these two elements, and the high analytical precision at the concentration levels analyzed. The high $\mathrm{SO}_{4}$ concentrations increase the analytical c.v. for $\mathrm{Cl}$ to $\sim 2.5$ percent. The large $\mathrm{SO}_{4} / \mathrm{F}$ equivalence ratio insures adequate analytical precision for the $\mathrm{SO}_{4}$ statistics. However, the high concentrations of $\mathrm{S}(-\mathrm{II})$ species in the source 1 water, and their potential for oxidation to $\mathrm{SO}_{4}$, add uncertainty to the $\mathrm{SO}_{4}$ statistics. The $P(\mathrm{~F})$ statistics are imprecise because of the low $F$ concentrations and small concentration difference between the two source waters. The precision and accuracy of the $P(\mathrm{As})$ statistics in this sytem suffer from the relatively high $P$ concentrations, and the high and variable levels of $\mathrm{S}(-\mathrm{II})$ species among the samples (Stauffer, 1980b).

The $P_{3}(S)$ (subscript identifies station) for $\mathrm{S}(-\mathrm{II}), \mathrm{Cl}$, $\mathrm{Na}, \mathrm{K}$, and $\mathrm{Li}$ are statistically equivalent. The $P_{4}(S)$ statistics for these four solutes are all significantly smaller than the $P_{3}(S)$ values, indicating that the water sample obtained from immediately below the confluence was biased in favor of source 1 water. The sampling bias reflects incomplete mixing of the two source waters. The steep gradient and adequate mixing length between stations 3 and 4 insure that $P_{4}(\mathrm{~S})$ values are unbiased (best estimate $P_{4}=0.375 \pm 0.007$ ). The equivalence of the $\mathrm{Cl}, \mathrm{Na}, \mathrm{K}$ and $\mathrm{Li}$ mixingfraction statistics indicates conservative behavior for the three alkalis in this system. Because of the high

TABLE 6.-Chemical and physical parameters of Calcite and two other unnamed sulfide-bearing springs in Yellowstone Canyon with the drainage of the mixed spring system

[Temperature, Eh, $\mathrm{pH}$, and $\mathrm{O}_{2}$ are field determinations; other analyses performed after return to Menlo Park Laboratory, except as noted]

\begin{tabular}{|c|c|c|c|c|c|c|c|c|c|}
\hline \multirow[b]{2}{*}{ Parameter' } & \multicolumn{6}{|c|}{$\begin{array}{l}\text { Stations along common discharge drainage } \\
\text { of two unnamed springs* }\end{array}$} & \multicolumn{2}{|c|}{ Mixing fraction ${ }^{2}$} & \multirow{2}{*}{$\begin{array}{c}\text { Concen- } \\
\text { tration } \\
\text { ration } \\
(5 / 4)\end{array}$} \\
\hline & Spring & 1 & $\begin{array}{c}\mathbf{2} \\
\text { Spring }\end{array}$ & 3 & 4 & 5 & $\overline{\mathbf{P}_{3}(\mathbf{S})}$ & $\overline{P_{4}(\mathbf{S})}$ & \\
\hline 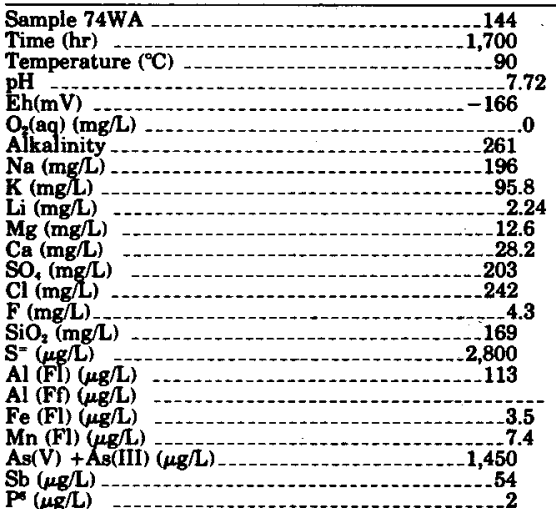 & $\begin{array}{c}142 \\
-1,400 \\
46 \\
5.98 \\
-94 \\
798 \\
7.0 \\
-28.5 \\
-227 \\
251 \\
112 \\
2.2 \\
72 \\
3,210 \\
239 \\
328 \\
190 \\
283 \\
742 \\
-61\end{array}$ & $\begin{array}{c}141 \\
-1,300 \\
40 \\
6.90 \\
-66 \\
\quad .0 \\
5 \sim 600 \\
116 \\
56.4 \\
1.09 \\
29.1 \\
232 \\
279 \\
127 \\
2.5 \\
78 \\
4,800 \\
243 \\
415 \\
215 \\
98 \\
710 \\
757\end{array}$ & $\begin{array}{c}143 \\
-1,500 \\
14 \\
7.45 \\
+14 \\
4.60 \\
207 \\
36.6 \\
14.1 \\
.22 \\
16.4 \\
62.0 \\
86 \\
25 \\
1.6 \\
68 \\
55 \\
11 \\
<4 \\
35 \\
89 \\
150 \\
-57 \\
-5\end{array}$ & $\begin{array}{c}140 \\
\sim 1,215 \\
23-26 \\
7.22 \\
-30 \\
.80 \\
-75.3 \\
34.8 \\
.65 \\
21.4 \\
141 \\
187 \\
78 \\
2.0 \\
68 \\
2,250 \\
128 \\
69 \\
113 \\
88 \\
395 \\
-53\end{array}$ & $\begin{array}{c}139 \\
-1,130 \\
19 \\
8.05 \\
+185 \\
5.10 \\
399 \\
63.0 \\
29.9 \\
.54 \\
19.4 \\
120 \\
159 \\
64 \\
2.0 \\
69 \\
<15 \\
94 \\
708 \\
108 \\
88 \\
280 \\
-56\end{array}$ & $\begin{array}{c}138 \\
\sim 1,030 \\
14.5 \\
8.35 \\
+139 \\
5.80 \\
-64.8 \\
64.8 \\
29.5 \\
20.56 \\
20.3 \\
123 \\
171 \\
63 \\
2.0 \\
66 \\
<15 \\
12 \\
<4 \\
6 \\
37 \\
270 \\
-60\end{array}$ & \begin{tabular}{l}
$-1 .-$. \\
n.a. \\
n.a. \\
n.a. \\
n.a. \\
n.a. \\
n.a. \\
.487 \\
.489 \\
.495 \\
.394 \\
.465 \\
.523 \\
.487 \\
.550 \\
n.a. \\
n.a. \\
n.a. \\
n.a. \\
n.a. \\
n.a. \\
\hdashline..- \\
n.a.
\end{tabular} & \begin{tabular}{l} 
n.a. \\
n.a. \\
n.a. \\
n.a. \\
n.a. \\
n.a. \\
.333 \\
.374 \\
.368 \\
.236 \\
.341 \\
.378 \\
.382 \\
.470 \\
n.a. \\
n.a. \\
n.a. \\
n.a. \\
n.a. \\
n.a. \\
\hdashline n.a. \\
n.a.
\end{tabular} & 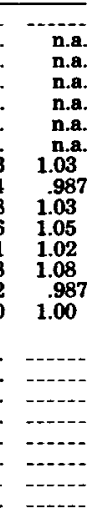 \\
\hline
\end{tabular}

* Filtered sample, the other samples are unfiltered.

IFf = filtered and field extracted; $F \mathbf{l}=$ filtered and lab extracted; $U I=$ unfiltered and lab extracted.

${ }_{2}^{2} \mathrm{P}_{3}(\mathrm{~S})$ is defined as the apparent fraction of water at gtation 3 which is source 1 water; similarly, $\mathrm{P}_{4}$ (S).

Concentration ratio of gtation 5 to station 4.

Not applicable.

Best estimate; sample poorly mixed.

Soluble reactive phosphorus as P (Strickland and Parsons, 1968) 
$\mathrm{K} / \mathrm{Al}$ atomic ratio (93 for source 1 , higher for source 2 ) and the very short hydraulic residence time in the system, the conservation of $\mathrm{K}$ is to be expected. The mean mixing fractions $\left(\bar{P}_{3}, \bar{P}_{4}\right)$ for the conservative elemental suite $(\mathrm{Na}, \mathrm{K}, \mathrm{Li}, \mathrm{Cl})$ are used to quantitatively evaluate the behavior of $\mathrm{Ca}, \mathrm{Mg}, \mathrm{Al}, \mathrm{Fe}, \mathrm{Mn}, \mathrm{As}$ and $\mathrm{P}$ in the mixed-water system.

The concentrations of $\mathrm{Mg}$ and $\mathrm{Ca}$ recovered at stations 4 and 5 indicate minor losses of both elements below the confluence $(1.3 \mathrm{mg} / \mathrm{L} \mathrm{Mg}$, or 6 percent; 6 $\mathrm{mg} / \mathrm{L} \mathrm{Ca}$ or 5 percent). Temperature-dependent mineral equilibria calculations performed using WATEQF (Plummer and others, 1976) revealed supersaturation with respect to carbonate and silicate minerals at station 4. The saturation indices $\left(I_{s}=\log _{10}(\right.$ IAP/KT $) *$ at station 4 were: calcite $\left(I_{s}=1.07\right)$; magnesite $\left(I_{s}=0.25\right)$; and well-ordered sepiolite $\left(I_{s}=0.35\right)$. The $\mathrm{pH}$ increase and temperature decrease below station 4 (table 6) result in increased supersaturation with respect to sepiolite at the lower station. Neighboring boiling "Calcite" spring is also strongly supersaturated with respect to both well-ordered and poorly ordered sepiolites $\left(I_{s}=4.22 ; I_{s}=2.63\right)$. The "Calcite" spring was near saturation with respect to calcite $\left(I_{s}=-0.14\right)$ and magnesite $\left(I_{s}=0.37\right)$.

The Yellowstone Canyon thermal springs are also supersaturated with respect to a broad class of aluminosilicates, especially the montmorillonites. Clearly, the potential exists for $\mathrm{Ca}$ and $\mathrm{Mg}$ solute losses via a variety of mineral reactions. However, because of the great stoichiometric excesses of $\mathrm{Mg}$ and $\mathrm{Ca}$ over $\mathrm{Al}$ in these springs, carbonates and pure silicates are likely to be the more important solubility controls. Wollast, MacKenzie, and Bricker (1968) noted that the

"IAP/KT is the ratio of ion-activity product to thermodynamic solubility constant.) precipitation of sepiolite is not kinetically hindered at low temperatures $\left(25^{\circ} \mathrm{C}\right)$.

Field-extractable soluble $\mathrm{Al}$ decreased rapidly below the confluence (table 7), whereas laboratoryextractable $\mathrm{Al}$ did not show a decrease until at least station 4, continuing the lag pattern noted earlier for the Azure Spring drainage channel.

Iron precipitation in the drainage (table 7) likely results from at least two mechanisms: amorphic FeS deposition from the high S(-II) waters accompanying the rapid $\mathrm{pH}$ rise, and Fe precipitation as amorphic hydrous oxide from the oxygenated waters as they attain positive Eh values (Hem,1977). Large quantities of black precipitate (presumed to be $\mathrm{FeS}$ ) were observed above station 3 in the mixed water, and especially above the confluence in the source 1 tributary. Reddish-brown hydrous oxide coatings were abundant in the drainage channel of the oxygenated $14^{\circ} \mathrm{C}$ source. The oxidation of both Fe(II) and S(-II) is probably mediated by the luxuriant growths of white filamentous bacteria observed in the drainage channel above station 4 (Castenholz, 1973). Calculations using WATEQF confirmed supersaturation with respect to amorphic $\mathrm{FeS}$ at station $1\left(I_{s}=0.90\right)$ and with respect to amorphic $\mathrm{Fe}(\mathrm{OH})_{3}$ at station $4\left(I_{s}=2.12\right)$.

Soluble $\mathrm{Mn}$ and $\mathrm{Fe}$ concentrations were characterized by minor losses prior to station 4 and losses of 60 and 95 percent, respectively, by station 5 (table 7). The increases in the $\mathrm{Mn} / \mathrm{Fe}$ ratio with distance below the confluence indicate a less rapid oxidation rate of $\mathrm{Mn}$ (II) than of $\mathrm{Fe}$ (II) in the aerated water. Singer and Stumm (1970) discussed the enormous kinetic enhancement of $\mathrm{Fe}$ (II) oxidation associated with bacterial oxidation. The rate of oxidation of $\mathrm{Mn}$ (II) increases with increasing $\mathrm{pH}$ and increasing $\mathrm{MnO}_{2}$ surface area, a catalytic effect (Morgan, 1967; Delfino and Lee, 1968). The observed delay in oxidation of $\mathrm{Mn}(\mathrm{II})$ and

TABLE 7.-Estimated solute losses following mixing in Yellowstone Canyon mixed spring and Madison River systems

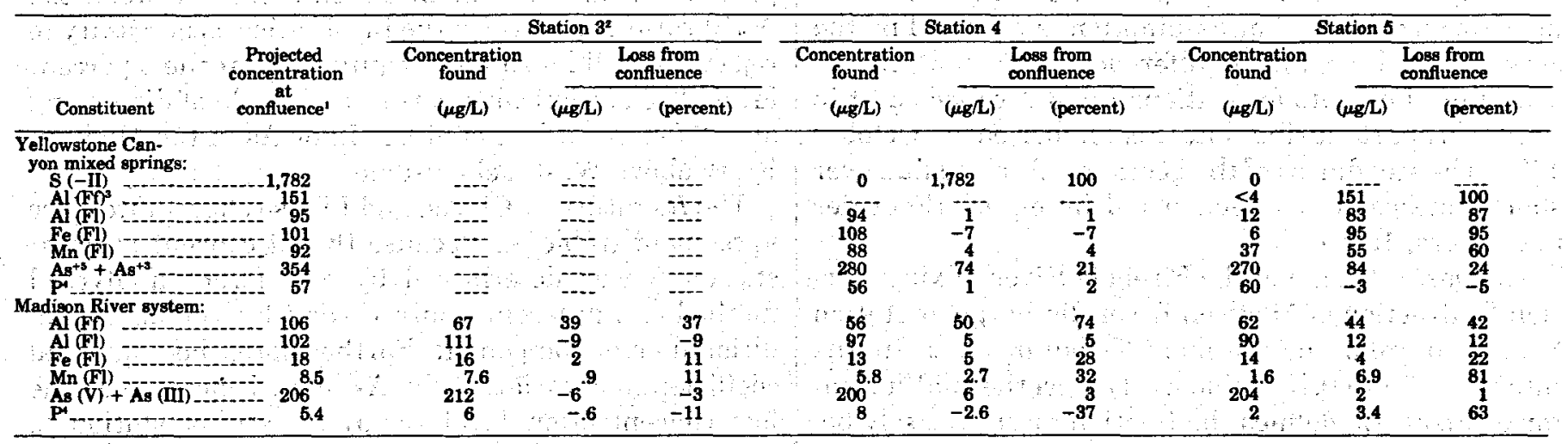

Computed from source waters using mean mixing fractions for $\mathrm{Na}, \mathrm{K}, \mathrm{Li}$ and $\mathrm{Cl}$ from tables 6 and 8 .
station in Yellowstone Canyon Mixed Spring System omitted due to nonrepresentativeness of collected sample.

'Station in Yellowstone Canyon Mixed Spring System omitted due
Tf $=$ filtered and field extracted; Fl = filtered and lab extracted.
tSoluble reactive phosphorus as P (Strickland and Parsons, 1968). 
hence the increase in the $\mathrm{Mn} / \mathrm{Fe}$ ratio down drainage fits the Mn oxidation model.

The relatively low concentrations of $\mathrm{S}(-\mathrm{II}), \mathrm{Fe}$, and $\mathrm{Al}$ found at station $2\left(14^{\circ} \mathrm{C}\right.$ source $)$ are probably residuals of higher concentrations prevailing before interaction with the atmosphere. The high $\mathrm{Mn} / \mathrm{Fe}$ ratio for source 2 is also evidence of the delayed oxidation of $\mathrm{Mn}$ (II) relative to $\mathrm{Fe}(\mathrm{II})$.

Soluble reactive $P$ shows no statistical evidence of precipitation losses below the confluence. Whereas $\mathrm{Fe}(\mathrm{II})$ and S(-II) are potential energy substrates for the filamentous bacteria in the channel, $P$ is used only for steady-state maintenance of the bacterial population. The precipitation of $\simeq 102 \mu \mathrm{g}$ of Fe/L between stations 4 and 5 did not result in a significant reduction in $\mathrm{P}$ or As concentration. The high $\mathrm{pH}(>8.0)$ is unfavorable for $\mathrm{P}$ and $\mathrm{As}(\mathrm{V})$ sorption on hydrous ferric oxides (see later discussion). An estimated 2 percent of the total solute As was lost between stations 4 and 5 , the region where the principal losses of $\mathrm{Fe}$ and $\mathrm{Mn}$ through oxidation occurred. The As loss is not statistically significant.

\section{MADISON RIVER SYSTEM}

The date/time group is different for each of the sampling sites in the Madison River system. Time of day can be expected to affect temperature, $\mathrm{pH}$, and dissolved $\mathrm{O}_{2}$ at a site because of diurnal effects of the solar cycle on heating and photosynthesis. The estimated fraction of Madison River water at station 3, which is derived from the Firehole River and calculated using solute concentrations (equation 2), is biased unless the solute concentrations were independent of time during September 18-21. Because the period September 18-21 was precipitation free for the water, and was a low-flow period for the Madison River, the assumption of time independence in solute concentrations is equivalent to assuming that the cold-spring and hot-spring fluxes in the Gibbon and Firehole River drainages were invariant during the 3-day span. One indication of the near correctness of that assumption is provided by the close comparisons (mean difference $<2$ percent) in two sets of total As data for stations 1 and 2, collected 11 to 14 days apart during late September-early October 1974. The steadiness of the geothermal solute flux over short timespans has been noted by others (Fournier and others, 1976).

The best estimate of the Firehole River mixing fraction $P_{3}$ (fraction of Madison River discharge at station 3 derived from the Firehole Tributary) lies in the interval 0.70 to 0.75 (table 8). The geothermal indicator element, $\mathrm{Li}$, defines the fraction most precisely because of the high analytical precision and the large concentration difference between the two tributaries.
The $P_{3}(\mathrm{As})$ value, 0.76, indicates that As being transported in the Gibbon and Firehole Rivers remains in solution below the confluence and above station 3 .

Using solute concentration ratios defined analogously to those for the Lower Basin, the geochemical behavior of $\mathrm{Li}$ and $\mathrm{As}$ can be contrasted with that of $\mathrm{Cl}$ in the Madison Canyon region. Let $R_{i / 3}(S)$ where $i=4,5,6$, be the ratio of solute $S$ concentration at station $i$ to the concentration at station 3 , immediately below the confluence. The $R_{4 / 3}(S)$ and $R_{5 / 3}(S)$ ratios apply to the Madison River between West Yellowstone and Madison Junction. The $R_{6 / 3}(S)$ ratios reflect the extensive dilution of Madison River water by stored water and other tributary water flowing into Hebgen Lake. Additions of geothermal water between Madison Junction and West Yellowstone are considered here to be negligible. This assumption is only approximately correct; however, inferences based on the solute ratio statistics are rather insensitive to minor unaccounted geothermal fluxes within Madison Canyon.

Elements which are well represented in nonthermal waters (particularly $\mathrm{K}, \mathrm{Ca}$, and $\mathrm{Mg}$ ) can be expected to have $R_{4}, R_{5}$ and $R_{6}$ ratios higher than for Cl. This was, in fact, observed (table 8). The $R_{4 / 3}$ and $R_{5 / 3}$ ratios for $\mathrm{K}$, $\mathrm{Ca}$, and $\mathrm{Mg}$ are only slightly higher than for $\mathrm{Cl}$ because of the very slight tributary development of the Madison River within the Madison Canyon. The $R_{5 / 3}(\mathrm{Cl})$ statistic shows that the water at Madison Junction has been diluted by approximately 5 percent when it arrives at West Yellowstone gaging station.

Elements of geothermal origin which behave conservatively in the river will have concentration ratios which are not statistically distinguishable from the $\mathrm{Cl}$ ratios. Nonconservative behavior is identifiable by concentration ratios significantly lower than for $\mathrm{Cl}$. Thus, the concentration ratios indicate that both $\mathrm{Li}$ and total As are conservative in the Madison Canyon (table 8). The mean percent difference between the $\mathrm{As} / \mathrm{Cl}$ and $\mathrm{Li} / \mathrm{Cl}$ ratios for stations 4 and 5 is only -0.3 percent. A -2.0 percent mean difference between the $\mathrm{As} / \mathrm{Cl}$ ratios, or between the $\mathrm{Li} / \mathrm{Cl}$ ratios, is necessary to reject the null hypothesis (equivalent) at the 5 percent level. The statistical test is thus capable of discerning an 2.0-percent loss of either $\mathrm{Li}$ or As in the Madison River above West Yellowstone.

The $R_{6}$ ratios for $\mathrm{Cl}, \mathrm{As}$, and $\mathrm{Li}$ also show quite close agreement (table 8). Because the $\mathrm{Cl}$ concentration at station 6 was determined by a different analytical method and different analyst, the $\mathrm{Cl}$ ratio has an additional error component. Furthermore, the analytical coefficients of variation for $\mathrm{As}$ and $\mathrm{Li}$ increase at the low concentration levels characteristic of station 6 . Hence, the small negative differences between $R_{6 / 3}(\mathrm{Li})$ and $R_{6 / 3}(\mathrm{Cl})$ and between $R_{6 / 3}(\mathrm{As})$ and $R_{6 / 3}(\mathrm{Cl})$ are 
TABLE 8.-Chemical and physical parameters of the Madison River drainage

[Temperature, $\mathrm{Eh}, \mathrm{pH}$, and $\mathrm{O}_{2}$ are field determinations; other analyses performed after return to Menlo Park Laboratory, except as noted]

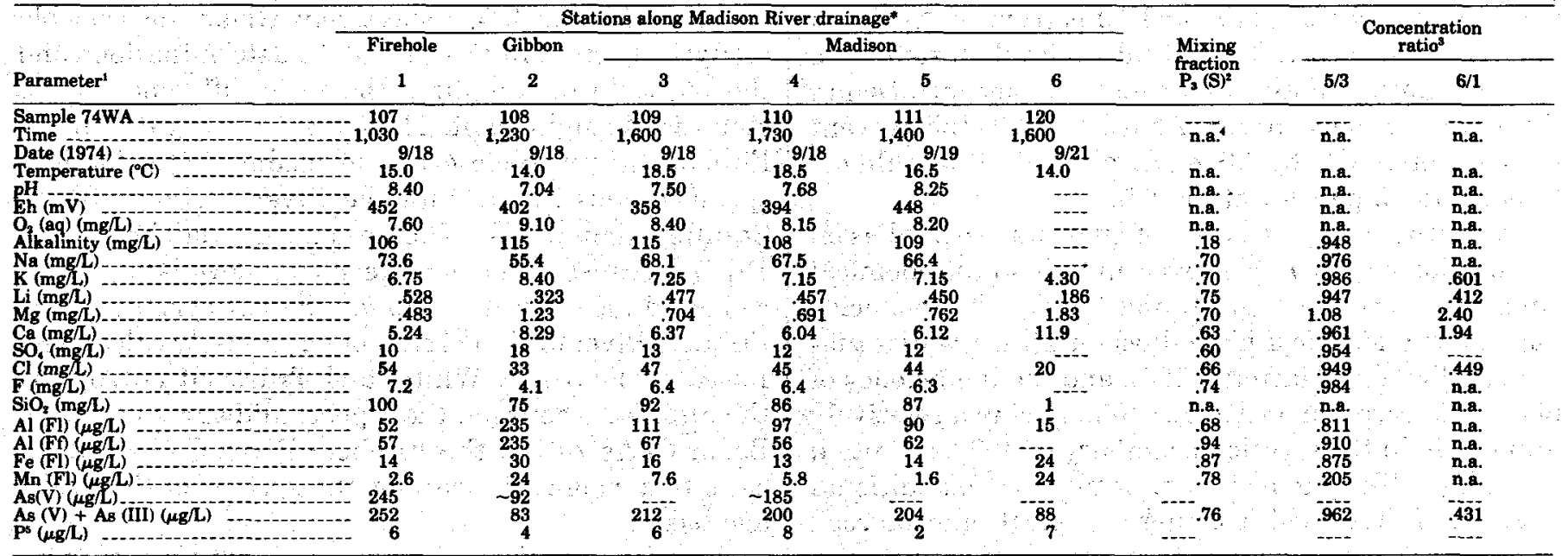

FFiltered sample, the others samples are unfiltered

Ff $=$ filtered and field extracted; $F I=$ filtered and lab extracted; $U 1=$ unfiltered and lab extracted

$\mathrm{P}_{3}$ (S) is defined as the apparent fraction of water at station 3 which is source 1 water

Concentration ratio station 5 to station 3, station 6 to station 3.

Solubplicable.

inconclusive evidence of $\mathrm{Li}$ and As losses in Hebgen Lake. The ratio comparisons suggest that only a minor fraction of the soluble $\mathrm{Li}$ and As fluxes in the Madison River are lost in Hebgen Lake during fall base-flow conditions. The near conservatism is not surprising since the elevated river water temperature and low suspended-solids load of the Madison should lead to short circuiting through the surface waters of Hebgen Lake. Similarly, Axtmann (1974) noted the near conservatism of total As in the Waikato River and Lake Taupo below Wairakei in New Zealand.

The mean $P$ concentration for the Firehole and Madison Rivers $(5.5 \mu \mathrm{g} / \mathrm{L})$ is typical of low levels found in unpolluted rivers derived from forested drainage basins; the present estimates are smaller by a factor of 20 than the $\mathrm{As}(\mathrm{V})$-biased $\mathrm{P}$ data previously reported by Boylen and Brock (1973) and Zeikus and Brock (1972) for the Madison River system.

The field-extracted Al estimates reveal a significant loss of Al immediately following the mixing of the Gibbon and Firehole Rivers (table 7). However, following the pattern described for the other drainages studies, the laboratory-extracted Al data reveal smaller decreases, occurring more slowly as a function of distance below the confluence. The methodological difference may the result of the formation of nonextractable $\mathrm{Al}$ polymers (Smith, 1971), which are depolymerized during storage in 0.1 molar $\mathrm{HNO}_{3}$. The loss of $\mathrm{Al}$ is not accompanied by a detectable loss of $\mathrm{Li}$.

The Gibbon River contains higher $\mathrm{Al}, \mathrm{Fe}$, and $\mathrm{Mn}$ concentrations than the Firehole River. The concentration of soluble Mn decreases gradually below the con- fluence to $\sim 1.6 \mu \mathrm{g} / \mathrm{L}$ near West Yellowstone; however, no significant change was detected in soluble iron (table 7). The large increases in $\mathrm{Mn}, \mathrm{Ca}$, and $\mathrm{Mg}$ concentration $(1,400,94,140$ percent, respectively) between stations 5 and 6 are a result of nonthermal waters entering Hebgen Lake from other drainage areas.

\section{SORPTION CONTROLS ON ARSENIC IN GEOTHERMAL WATERS}

Amorphic hydrous Fe oxides are the most efficient As scavengers in the class of amorphic precipitates formed by $\mathrm{Al}, \mathrm{Fe}$, and $\mathrm{Mn}$ in natural waters (Gulledge and O'Connor, 1973; O'Connor, 1974; Singer, 1974). The almost quantitative removal (>99 percent) of As(V) from neutral to acidic solutions using ferric hydroxide coprecipitation has been the chemical basis of many concentration schemes for analyzing As at low levels in the environment (Portmann and Riley, 1964). Furthermore, it is well known that the sorption affinity of ferric hydroxide for $\mathrm{As}(\mathrm{V})$ is greatly reduced under alkaline conditions (Portmann and Riley, 1964; O'Connor, 1974). Trivalent As is inefficiently sorbed at all pH values. For example, Logsdon, Sorg, and Symons (1974) found only about 50-percent removal of As(III) (initially at the $0.3 \mathrm{mg} / \mathrm{L}$ level) using a $30 \mathrm{mg} / \mathrm{L}$ ferric sulfate dose; the percentage removed was independent of acidity in the $\mathrm{pH}$ range 6 to 9 . For $\mathrm{As}(\mathrm{V})$ (initially at $0.05 \mathrm{mg} / \mathrm{L}$ ) $0^{\prime}$ Connor (1974) reported 88 percent removal at $\mathrm{pH} 8.0$ in the presence of $10 \mathrm{mg} / \mathrm{L}$ $\mathrm{Fe}$ (III).

$\mathrm{Al}$ is less effective than $\mathrm{Fe}$ at scavenging both $\mathrm{As}(\mathrm{III})$ 
and $\mathrm{As}(\mathrm{V})$, the differences increasing above $\mathrm{pH}$ 7:0. Logsdon, Sorg, and Symons (1974) found that $30 \mathrm{mg} / \mathrm{L}$ alkali aluminium sulfate (alum) treatments removed about 90 percent of $A s(V)$ and 10 percent of $A s(I I I)$ in the $\mathrm{pH}$ range 5 to 7 . The initial As levels tested were $0.30 \mathrm{mg} / \mathrm{L}$, very similar to the total As concentration in the lower Firehole River. Above pH 7.0, the percent removal of $\mathrm{As}(\mathrm{V})$ by $30 \mathrm{mg} / \mathrm{L}$ alum declined almost linearly to 15 percent at $\mathrm{pH} 8.5$.

The authors are not aware of quantitative studies on As sorption by $\mathrm{MnO}_{2}$. However, in light of the chemical similarity between $\mathrm{H}_{3} \mathrm{AsO}_{4}$ and $\mathrm{H}_{3} \mathrm{PO}_{4}$ (the two acids have nearly identical $\mathrm{pK}$ values for all three dissociations, Sillen and Martell; 1964), and the inefficiency of phosphate sorption on $\mathrm{MnO}_{2}$, Mn may play a relatively minor role in the sorption chemistry of As. As sorption on $\mathrm{MnO}_{2}$ is likely to be insignificant for two additional reasons: (1) The acid leaching of typical igneous rock solubilizes great stoichiometric excesses of both $\mathrm{Fe}$ and Al as compared to $\mathrm{Mn}$; (2) the oxidation and precipitation of $\mathrm{Mn}$ is often delayed in geothermal waters until the $\mathrm{pH}$ is far too high to effect efficient removal of $\mathrm{As}(\mathrm{V})$.

The conservative behavior of total As in Octopus Spring is an expected consequence of the high $\mathrm{pH}$ and very high $\mathrm{As} / \mathrm{Fe}$ atomic ratio of 570 . Furthermore, very large $\mathrm{As} / \mathrm{Fe}$ ratios are typical of alkaline hot springs throughout the major hot-spring basins. In Azure Spring, the initial soluble $\mathrm{As} / \mathrm{Al}$ atomic ratio is only 1.20 , in contrast to the $\mathrm{As} / \mathrm{Fe}$ atomic ratio of 183 . However, $\mathrm{Al}$ precipitation occurs prior to station 3 in the drainage channel, and prior to the oxidation of a significant amount of As(III). This oxidation lag can be expected to greatly reduce the effectiveness of As removal by oxidic Al precipitates. Coprecipitation of $\mathrm{Al}$ with $\mathrm{SiO}_{2}$ to form montmorillonite (R. O. Fournier, oral communication, 1975) may also reduce As losses onto oxidic $\mathrm{Al}$ in the high-Al springs of the River Group. Thermodynamic calculations indicate Azure Spring is supersaturated with respect to several montmorillonites.

The levels of both $P$ and As in the Yellowstone Canyon warm spring indicate that, even in the presence of anomalously high Fe levels $(\simeq 200 \mu \mathrm{g} / \mathrm{L})$, the removal of As by sorption is relatively insignificant in this alkaline spring water. The low Fe/As molar ratios, the very large $\mathrm{As}(\mathrm{III}) / \mathrm{As}(\mathrm{V})$ initial ratios, and the rapidly rising $\mathrm{pH}$ after the emergence of the spring water at the ground surface all combine to reduce sorption by hydrous $\mathrm{Fe}$ oxides as an important mechanism affecting As in the drainages of alkaline hot springs.

As behaves nearly conservatively during the long base flow period (losses $<2$ percent of flux) in the Madison-Firehole River system. In addition to evi- dence previously discussed, samples obtained from the Firehole River at Madison Junction and just below Lower Basin (early October 1974) had Cl/As atomic ratios of 466 , and 456 , respectively. Given the probable analytical errors in the $\mathrm{Cl}$ and As determinations and the lag time in sampling, the ratio difference is not statistically significant. The $\mathrm{Cl} / \mathrm{As}$ atomic ratio in the Firehole River is close to the median ratio for hotspring groups in the Firehole River drainage (R. E. Stauffer and J. M. Thompson, unpublished data, 1975). Because of inadequate spring flow data, a flowweighted mean $\mathrm{Cl} / \mathrm{As}$ ratio for the hot springs in the Firehole River drainage cannot be precisely calculated. Based on Fournier, White, and Truesdell (1976) and the difference between the Upper, Midway, and Lower Basin Cl/As ratios, the Firehole River Cl/As ratio is close to a weighted mean for the springs of the drainage basin.

Near conservatism of As during low flow occurs because of the following factors: (1) The soluble Fe/As ratio is too low to significantly affect As by sorption or coprecipitation; (2) although the suspended solids may be assumed to have surface-active coatings of Fe oxides (Jenne, 1968, 1977), the concentration of suspended inorganic solids in the rivers is low during the low-flow period; (3) the alkaline $\mathrm{pH}$ of the river during daylight hours is suboptimal for $\mathrm{As}(\mathrm{V})$ sorption on Fe oxides.

During high runoff periods (principally the MayJune snowmelt period, Fournier and others, 1976) the $\mathrm{pH}$ of the Madison River drops and the riverborne flux of sorption-active clastics increases dramatically. During such periods the increased contact opportunity between As (V) and the amorphic Fe oxide coatings on the particulates might be expected to result in significant losses of soluble As in the Madison River. The most likely sink for sorbed As(V) during spring runoff is the sediments of Hebgen Lake.

The Cl/As atomic ratio for the Gibbon River at Madison Junction is 760 , a value significantly higher than the ratios for key indicator springs in both the Gibbon $(\mathrm{Cl} / \mathrm{As}=400 \pm 25)$ and Norris $(\mathrm{Cl} / \mathrm{As}=543 \pm 11)$ hotspring basins (R. E. Stauffer and J. M. Thompson, unpublished data, 1975). The Gibbon and Norris thermal basins constitute most of the geothermal activity in the Gibbon River drainage basin (Fournier and others, 1976). The $\mathrm{Cl} / \mathrm{Li}$ atomic ratio for the Gibbon River at Madison Junction is 20.1, intermediate among the mean ratios for the Norris $(23.8 \pm 0.5)$ and Gibbon (Gibbon Meadows area: $\mathrm{Cl} / \mathrm{Li}=19.2 \pm 1.4$; Artist Paint Pots: $\mathrm{Cl} / \mathrm{Li}=16.4 \pm 0.4$ ) geyser basins (R. E. Stauffer and J. M. Thompson, unpublished data, 1975). On the basis of the $\mathrm{Cl} / \mathrm{Li}$ ratios, it is possible to infer that in excess of 50 percent of the Gibbon River $\mathrm{Cl}$ flux originates in the Gibbon Geyser Basin. An immediate im- 
plication of this inequality is that 60 percent or more of the geothermal As flux in the Gibbon River drainage basin during base-flow conditions is removed by precipitation and sorption processes. The high Gibbon River $\mathrm{Cl} / \mathrm{As}$ ratio probably results from $\mathrm{As}(\mathrm{V})$ sorption on hydrous $\mathrm{Fe}$ oxides and oxidic $\mathrm{Al}$ above Gibbon Canyon as the river's $\mathrm{Cl} / \mathrm{As}$ ratio is also elevated in the canyon. Some As may also be precipitated as $\mathrm{FeAsO}_{4}$ and realgar (AsS) in the acidic spring -environments (depending on redox potential). Acid-sulfate waters containing high levels of $\mathrm{Fe}$ and $\mathrm{Al}$ mix with poorly buffered high-Cl, high-As waters in both the Norris and Gibbon thermal basin (Allen and Day, 1935; White, 1957); the $\mathrm{pH}$ of the weakly acidic water rises, and large amounts of $\mathrm{Fe}$ and $\mathrm{Al}$ precipitate. The mixing of two geochemically distinct water types in the Norris-Gibbon region thus produces conditions which are optimal for the sorption of $\mathrm{As}(\mathrm{V})$ on both $\mathrm{Fe}$ and $\mathrm{Al}$ precipitates. The time delay required for mixing and Fe(II) oxidation (Brock and others, 1976) helps insure that As initially in the form of As (III) has been oxidized to the more readily sorbing $A s(V)$.

\section{ARSENIC FLUX OF THE MADISON RIVER}

Using the September concentration estimate of 202 $\mu \mathrm{g} / \mathrm{L}$ of $\mathrm{As}$ and available earlier discharge measurements during September low flow at the West Yellowstone gaging station $\left(12.7 \mathrm{~m}^{3} / \mathrm{s}\right.$, U.S. Geological Survey, 1974; flow measurement was discontinued after 1973), the estimated base flow total soluble As flux for the Madison River is $220 \mathrm{~kg} /$ day, 90 percent of which is contributed by the Firehole River. An additional 25 to $30 \mathrm{~kg} / \mathrm{day}$ of As is precipitated in the Gibbon River drainage basin. Because the September geothermal As flux can be assumed to be representative of the daily flux on an annual basis (Fournier and others, 1976; R. E. Stauffer and J. M. Thompson, unpublished data, 1975), the annual total (soluble + particulate) As flux of the Madison River at West Yellowstone is $\simeq 90,000 \mathrm{~kg}$. It is likely that particulate As deposited in the Gibbon drainage basin is flushed out during peak discharge in May and June and deposited in the sediments of Hebgen Lake.

The annual As flux for the Madison River is less than the flux estimate by Axtmann (1974) for Wairakei (158 metric tons) and the atmospheric As flux estimated for the ASARCO Copper smelter in Tacoma, Wash. (150,000 kg/year, Crecelius, 1975). The Tacoma smelter acquired notoriety as a result of its high As flux (Lawson, 1975). Swain (1949) reported an atmospheric As flux of 22.5 metric tons/day for the Anaconda Smelter at Anaconda, Mont., a value which is nearly 100 times the Madison River flux. The reason for the large discrepancy between the present ASARCO and histori- cal Anaconda fluxes is unclear; however, the high Anaconda figure applies to a period prior to any pollution abatement, and $A s$ is currently recovered as a byproduct at the Tacoma plant: Because the smelter As flux is almost exclusively the highly toxic particulate $\mathrm{As}_{2} \mathrm{O}_{3}$ (Crecelius, 1975), and the Madison River flux is dominantly soluble $\mathrm{As}(\mathrm{V})$ at the $200 \mu \mathrm{g} / \mathrm{L}$ level, an important distinction exists between the environmental impacts of the two As sources. At levels above $1 \mathrm{mg} / \mathrm{L}$ in drinking water, As is associated with long-term toxicity effects in humans, As(III) being notably more toxic than As(V) (Penrose, 1974).

During low-flow conditions the total As concentration at the Hebgen Dam spillway is about 85 to 90 $\mu \mathrm{g} / \mathrm{L}$, or about 75 percent, above the U.S. Public Health rejection limit for municipal water supplies $(50 \mu \mathrm{g} / \mathrm{L}$, Environmental Protection Agency, 1972). With increasing distance downriver, this level is presumed to be progressively reduced by dilution and sorption on clastics.

\section{POTENTIAL ECOLOGICAL SIGNIFICANCE OF ARSENIC}

The ecological role of As in the microbiological communities of the hot-spring drainages, and in the receiving rivers, is mainly a subject of conjecture. As is known to be oxidized and reduced (between As(III) and $\mathrm{As}(\mathrm{V})$ ) by microorganisms under a variety of natural conditions (Johnson, 1972; Myers and others, 1973; Pilson, 1974). As is also concentrated by a factor of 5,300 by the dominant macrophyte in the Waikato River (Axtmann, 1974, 1975). However, as Penrose (1974) noted, the concentration factors are likely to be highly dependent on aquatic species, as well as redox state of the As. Nothing is known at present about the As concentration factors for algae and macrophytes inhabiting geothermally derived waters in Yellowstone Park. Because of the chemical similarity between $\mathrm{AsO}_{4}{ }^{-3}$ and $\mathrm{PO}_{4}^{-3}$, and the importance of $\mathrm{P}$ as a critical nutrient for all plant forms, both the low levels of $P$ and the very high $\mathrm{As}(\mathrm{V}) / \mathrm{P}$ ratios for many of the hot springs and receiving waters may be of enormous ecological significance in Yellowstone Park. Limnetic environments enriched in As have become dominated by the relatively tolerant blue-green algae (J. Shapiro, oral communication, 1978), suggesting that the As/P gradients in Yellowstone thermal waters may also act to select blue green. Oceanographers have noted that the $\mathrm{As} / \mathrm{P}$ atomic ratio approaches 1.0 in the oligotrophic waters of the ocean (Portmann and Riley, 1964; Johnson and Pilson, 1972b). Penrose (1974) has noted that marine fish have relatively high As contents, probably as a result of concentration within the food chain and the effects of the As/P ratio on the phytoplankton. As concentration in phytoplankton is also 
the probable cause of the high As concentration in organically rich marine shales (Onishi and Sandell, 1955). In Octopus Spring the As(V)/P molar ratio reaches 350 , two orders of magnitude higher than the upper bound ratios likely to occur in the ocean. Even in the Madison River the As(V)/P ratio is about 15.

\section{CONCLUSIONS}

1. Soluble $\mathrm{Al}, \mathrm{Fe}$, and $\mathrm{Mn}$ approach low limiting values of $<5.0,1.0$, and $1.0 \mu \mathrm{g} / \mathrm{L}$, respectively, in the least diluted high-Cl waters of the Norris and Upper Geyser Basins. The springs so characterized represent zones of highest enthalpy flux in the park. The levels of $\mathrm{Al}, \mathrm{Fe}$, and $\mathrm{Mn}$ do not appear to correlate with the presence or absence of dissolved $\mathrm{S}(-\mathrm{II})$.

2. The soluble-Mn levels are strikingly elevated (approximately two orders of magnitude) in alkaline springs of "mixed water" origin. These springs include the Mammoth hot springs, Steady Geyser, the unnamed spring north of the Old Faithful highway interchange, and the warm springs in the Yellowstone Canyon. The $\mathrm{Mn} / \mathrm{Fe}$ atomic ratio is $>1$ in almost all of the alkaline springs of mixed origin, the ratio tending to increase with temperature.

3. The $\mathrm{Mn} / \mathrm{Fe}$ ratio increases along the drainage channels of S(-II)-containing springs of mized origin. The increase in the ratio probably reflects the slower rate of $\mathrm{Mn}$ (II) vs $\mathrm{Fe}$ (II) oxidation and the less effective solubility controls on Mn(II) at low temperatures.

4. Al precipitates rapidly in the relatively rare boiling springs containing elevated levels of the element. Al precipitation apparently occurs in Azure Spring prior to emergence of the water at the surface; the reaction proceeds virtually to completion at $89^{\circ} \mathrm{C}$ and $\mathrm{pH}<7.5$.

5. $\mathrm{Li}$, and to a lesser extent $\mathrm{K}$, behave nonconservatively if $\mathrm{Al}$ is being precipitated from hot-spring waters. The most likely mechanism of Li removal is through the formation of Li-bearing aluminosilicate minerals.

6. $P$ is present in very low concentrations $(\simeq 2 \mu \mathrm{g} / \mathrm{L})$ in undiluted hot-spring waters of the Upper, Lower, and Norris Basins. Higher concentrations of $P$ are associated with warm springs of mixed-water origin.

7. The As(III)/As(V) ratio in these thermal waters varies over three orders of magnitude and is strongly bimodally distributed according to whether or not S(-II) is present in detectable quantities.

8. Arsenite is rapidly oxidized to $\mathrm{As}(\mathrm{V})$ in the hot- spring drainages, but only after the volatilization and oxidation of S(-II).

9. Total As is essentially conservative (losses under 2 percent) in all of the surface-water systems studied, with the prominent exception of the Gibbon River. The major losses of total dissolved As in the Gibbon River occur above Gibbon Canyon and are hypothesized to result from $A s(V)$ sorption on oxidic $\mathrm{Fe}$ and $\mathrm{Al}$ formed as a result of the mixing of acid-sulfate and alkaline high-Cl waters in the upper Gibbon drainage basin.

10. The high levels of $\mathrm{As}$, the variable $\mathrm{As}(\mathrm{III}) / \mathrm{As}(\mathrm{V})$ ratios, and the extraordinarily high As/P ratios in Yellowstone geothermal waters are potential adverse ecological factors in the park.

\section{REFERENCES CITED}

Allen, E. T., and Day, A. L., 1935, Hot springs of the Yellowstone National Park: Carnegie Inst. Washington Pub. No. 466, 525 p. American Public Health Association, 1971, Standard methods for the examination of water and wastewater: Washington, D.C., 874 p.

Axtmann, R. C., 1974, An environmental study of the Wairakei power plant: Physics and Eng. Lab. Report. 445, Dept. Sci. and Indus. Research, Lower Hutt, New Zealand, 38 p.

1975, Environmental impact of a geothermal power plant: Sci., v. 187 , p. $795-803$.

Ball, J. W., Jenne, E. A., and Burchard, J. M., 1976, Sampling and preservation techniques for waters in geysers and hot springs, with a section on gas collection by $A$. $H$. Truesdell: Workshop on Sampling Geothermal Effluents, 1st, Proc., Environmental Protection Agency-600/9-76-011, p. 218-234.

Bargar, K. E., Beeson, M. H., Fournier, R. O., and Muffler, L. J. P., 1973, Present-day deposition of lepidolite from thermal waters in Yellowstone National Park: American Mineralogist, v. 58, p. 901-904.

Barnes, H. L., 1967, Geochemistry of hydrothermal ore deposits: New York, Holt, Rinehart and Winston, $670 \mathrm{p}$.

Baumann, E. W., 1974, Determination of parts per billion sulfide in water with the sulfide-selective electrode: Anal. Chemistry, v. 46 , p. $1345-1347$.

Bowen, F. S., 1926, The ratio of heat losses by conduction and by evaporation from any water surface: Phys. Rev., v. 27, p. 779 787.

Boylen, C. W., and Brock, T. D., 1973, Effects of thermal additions from the Yellowstone geyser basins on the benthic algae of the Firehole River: Ecology, v. 54, p. 1282-1291.

Brock, T. D., 1967, Relationship between standing crop and primary productivity along a hot spring thermal gradient: Ecology, v. 48, p. 566-571.

1969, Vertical zonation in hot spring algal mats: Jour. Phycologia, v. 8, p. 201-205.

Brock, T. D., and Brock, M. L., 1966, Temperature optima for algal development in Yellowstone and Iceland hot springs: Nature, v. 209, p. 733-734.

1967, Methodology for measurement of chlorophyll, primary productivity, photophosphorylation, and macro-molecules in benthic algal mats: Limnology and Oceanography, v. 12, p. $600-605$.

1968a, Measurement of steady-state growth rates of a thermophilic alga directly in nature: Jour. Appl. Bacteriology, v. 95, p. 811-815. 
-1968b, Relationship between environmental temperature and optimum temperature of bacteria along a hot spring thermal gradient: Jour. Appl. Bacteriology, v. 31, p. 54-58.

1969a, Effect of light intensity on photosynthesis by thermal algae adapted to natural and reduced sunlight: Limnology and Oceanography, v. 14, p. 334-341.

$-1969 \mathrm{~b}$, Recovery of a hot spring community from a catastrophe: Jour. Phycologia, v. 5, p. 75-77.

Brock, T. D., Brock, M. L., Bott, T. L., and Edwards, M. R., 1971, Microbial life at $90 \mathrm{C}$ : the sulphur bacteria of Boulder Spring: Jour. Bacteriology, v. 107, p. 303-314.

Brock, T. D., Cook, Susan, Petersen, S. and Mosser, J. L., 1976, Biogeochemistry and bacteriology of ferrous iron oxidation in geothermal habitats: Geochim. et Cosmochim. Acta, v. 40, p. 493-500.

Browne, P. R. L., 1969, Sulfide mineralization in a Broadlands geothermal drillhole: Econ. Geol., v. 64, p. 156-159.

Castenholz, R. W., 1973, The possible photosynthetic use of sulfide by the filamentous phototrophic bacteria of hot springs: Limnology and Oceanography, v. 18 , p. $863-877$.

Crecelius, E. A., 1975, The geochemical cycle of arsenic in Lake Washington and its relationship to other elements: Limnology and Oceanography, v. 20, p. 441-451.

Delfino, J. J., and Lee, G. F., 1968, Chemistry of manganese in Lake Mendota, Wisconsin: Environmental Sci. and Technology, v. 2, p. $1094-1100$.

Ellis, A. J., 1963, The effect of temperature on the ionization of hydrofluoric acid: Jour. Chem. Soc., London, p. 4300-4304. 1967, The chemistry of some explored geothermal systems, in Barnes, H. L., ed., Geochemistry of hydrothermal ore deposits: New York, Holt, Rinehart and Winston, p. 465-514.

1969, Present-day hydrothermal systems and mineral deposition: Commonwealth Mining and Metallurgical Cong., 9th, 1969, United Kingdom, Proc., p. 1-30.

1970, Quantitative interpretation of chemical characteristics of hydrothermal systems: U.N. Symposium on the Development and Utilization of Geothermal Resources, Pisa, Italy.

-1973, Chemical processes in hydrothermal systems-A review: International Symposium on Hydrogeochemistry and Biogeochemistry, Japan, 1970, Proc., v. 1, Hydrogeochemistry, p. 1-26.

Ellis, A. J., and Wilson, S. H., 1960, The geochemistry of alkali metal ions in the Wairakei hydrothermal system: New Zealand Jour. Geology and Geophysics, v. 3, p. 593-617.

Environmental Protection Agency, 1972, Water Quality Criteria: Washington, U.S. Govt. Printing Office, 56 p.

Fournier, R. O., and Truesdell, A. H., 1974, Geochemical indicators of subsurface temperature-Part 2, Estimation of temperature and fraction of hot water mixed with cold water: U.S. Geol. Survey Jour. Research, v. 2, p. 263-269.

Fournier, R. O., White, D. E., and Truesdell, A. H., 1974, Geochemical indicators of subsurface temperature-Part 1, Basic assumptions: U.S. Geol, Survey Jour. Research, v. 2, p. 259-262.

1976, Convective heat flow in Yellowstone National Park: U.N. Geothermal Symposium, 2d, San Francisco, 1975, Proc., p. 731-739.

Gulledge, J. J., and O'Connor, J. T., 1973, Removal of arsenic (V) from water by adsorption on aluminum and ferric hydroxides: Am. Water Works Assoc. Jour., v. 5, p. 548-552.

Hem, J. D., 1977, Reactions of metal ions at surfaces of hydrous iron oxide: Geochem. et Cosmochim. Acta, v، 41, p. 527-538.

Hogg, R. V., and Craig, A. T., 1970, Introduction to mathematical statistics [3d ed.,]: London, Macmillan, $415 \mathrm{p}$.

Jenne, E. A., 1968, Controls on Mn, Fe, Co, Ni, Cu, and $\mathrm{Zn}$ concentrations in soils and water; the significant role of hydrous $\mathrm{Mn}$ and Fe oxides: Adv. Chemistry Ser. 73, p. 337-387.

1977, Trace element sorption by sediments and soils - sites and processes, in Chappel, W. and Petersen, K., eds., Symposium on molybdenum in the environment, v. 2: New York, M. Dekker, Inc., p. 425-553.

Johnson, D. L., 1972, Bacterial reduction of arsenate in sea water: Nature, v. 240, p. 44-45.

Johnson, D. L., and Pilson, M. E. Q., 1972a, Spectrophotometric determination of arsenite, arsenate, and phosphate in natural waters: Anal. Chim. Acta, v. 58, p. 289-299.

$1972 b$, Arsenate in the western North Atlantic and adjacent regions: Jour. Marine Research, v. 30, p. 140-149.

Kennedy, V. C., Zellweger, G. W., and Jones, B. F., 1974, Filter pore-size effects on the analysis of $\mathrm{Al}, \mathrm{Fe}, \mathrm{Mn}$, and $\mathrm{Ti}$ in water: Water Resources Researvh; v. 10, p. 785-790.

Kennedy, V. C., Jenne, E. A., and Burchard, J. M., 1976, Backflushing filters for field processing of water samples prior to traceelement analyses: U.S. Geol. Survey Open-File Report 76-126, p. 1-12.

Lawson, H. G., 1975, Smelter's emissions threaten populace, but so does possible loss of 1,000 jobs: Wall Street Jour., 16 July 1975 , p. 30.

Logsdon, G. S., Sorg, T. J., and Symons, J. M., 1974, Removal of heavy metals by conventional treatment: Water Quality Conference, 16th, Proc., v. 71, no. 108, p. 111-133.

Mackereth, F. J. H., 1963, Some methods of water analysis for limnologists: Freshwater Biol. Assoc. Scientific Pub., v. 21, 71 p.

Mahon, W. A. J., 1964, Fluorine in the natural thermal water of New Zealand: New Zealand Jour. Sci., v. 7, p. 3-28.

Marler, G. D., 1973, Inventory of thermal features of the Firehole River geyser basins and other selected areas of Yellowstone National Park: NTIS PB-221 289, Springfield, VA, 648 p.

Morgan, J. J., 1967, Chemical equilibria and kinetic properties of manganese in natural waters, in Faust, S. D., and Hunter, J. V., eds., Principles and applications of water chemistry: New York, John Wiley, p. 561-622.

Myers, D. J., Heimbrook, M. E., Osteryoung, J., and Morrison, S. M., 1973, Arsenic oxidation state in the presence of microorganisms: examination by differential pulse polarography: Environmental Letters, v. 5, p. 53-61.

Nordstrom, D. K., and Jenne, E. A.; 1977, Fluorite solubility equilibria in selected geothermal waters: Geochim. et Cosmochim. Acta, v. 4, p. 175-188.

O'Brien, D. J., and Birkner, F. B., 1977, Kinetics of oxygenation of reduced sulfur species in aqueous solution: Environmental Sci. and Technology, v. 11, p. 1114-1120.

O'Connor, J. T., 1974, Removal of trace inorganic constituents by conventional treatment processes: Water Quality Conf., 16th, Proc., v. 71, n. 108 p. 99-110.

Onishi, Hiroshi, and Sandell, E. B., 1955, Geochemistry of arsenic: Geochim. et Cosmochim. Acta, v. 7, p. 1-33.

Penrose, W. R., 1974, Arsenic in the marine and aquatic environments: Analysis, occurrence, and significance: Chem. Rubber Co. Critical Rev., Environmental Control, v. 4, no. 4, p. 465-482.

Pilson, M. E. O., 1974, Arsenate uptake and reduction by Pocillopora verrucosa: Limnology and Oceanography, v. 19, p. 339-341.

Plummer, L. N., Jones, B. F., and Truesdell, A. H., 1976, WATEQF, A Fortran IV version of WATEQ, a computer program for calculating chemical equilibria of natural waters: U.S. Geol. Survey, Water Resources Inv. 76-13, 61 p.

Portmann, J. E., and Riley, J. P., 1964, Determination of arsenic in sea water, marine plants, and silicate and carbonate sediments: Anal. Chim. Acta, v. 31, p. 509-519.

Reay, P. F., 1973, Arsenic in the Waikato River system: Pollution Research Conference, Wairakei, 20-21 June 1973, Proc., New 
Zealand Dept. Sci. and Indus. Research Inf. Ser. No. 97, p. 365376.

Ritchie, J. A., 1973, A determination of some base metals in Broadlands geothermal waters: Physics and Eng. Lab. Rept. 2164, Dept. Sci. and Indus. Research, Lower Hutt, New Zealand, 24 p.

Rowe, J. J., Fournier, R. O., and Morey, G. W., 1973, Chemical analysis of thermal waters in Yellowstone National Park, Wyoming, 1960-65: U.S. Geol. Survey Bull. 1303, 31 p.

Sillen, L.G., and Martell, A. E., 1964, Stability constants of metal-ion complexes: Chem. Soc., London, no. 17, 754 p.

Singer, P. C., 1874, Chemical processes for the removal of trace metals from drinking waters: Water Quality Conf., 16th, Proc., v. 71, no. 108, p. $91-98$.

Singer, P. C., and Stumm, W., 1970, Acidic mine drainage: The rate-determining step: Sci., v. 167, p. 1121-1123.

Smith, R. W., 1971, Relations among equilibrium and non equilibrium aqueous species of aluminum hydroxy complexes, in Gould, R. F., ed., Nonequilibrium systems in natural water chemistry: Adv. Chemistry Ser. 106, p. 250-279.

Stauffer, R. E., 1977, Measuring total antimony in geothermal waters by flame atomic absorption spectrometry: U.S. Geol. Survey Jour. Research, v. 5, p. 807-809.

1980a, Bias evaluation of the cation exchange method for chloride and sulfate: Canadian Jour. Fisheries and Aquatic Sci. (in press).

$1980 \mathrm{~b}$, Molybdenum-blue applied to arsenic and phosphorus determinations in fluoride and silica rich geothermal waters: Environmental Sci. and Technology (in press).

Strickland, J. D. H., and Parsons, T. R., 1968, A practical handbook of seawater analysis: Canadian Fish Resources Board, Ottawa, $211 \mathrm{p}$.

Swain, R. E., 1949, Smoke and fume investigations: A historical review: Indus. and Eng. Chemistry, v. 41, p. 2384-2388.
Thompson, J.M., Presser, R. S. Barnes, R. B., and Bird, D. E., 1975, Chemical analysis of the waters of Yellowstone National Park, Wyoming from 1965 to 1973: U.S. Geol. Survey Open-File Report 75-25., $53 \mathrm{p}$.

U.S. Geological Survey, 1974, Water Resources Data for Montana; Part 1, Surface Water Records 1973: U.S. Geological Survey, $278 \mathrm{p}$.

Walter, M..R., Bauld, J., and Brock, T. D., 1972, Siliceous algal and bacterial stromatolites in hot spring and geyser effluents of Yellowstone National Park: Sci., v. 173, p. 402-405.

Weissberg, B. G., 1969, Gold-silver ore-grade precipitates from New Zealand theprmal waters: Econ. Geology, v. 64, p. 95-108.

White, D. E., 1957, Thermal waters of volcanic origin: Geol. Soc. America Bull., v. 68, p.-1637-1658.

1967, Mercury and base-metal deposits with associated thermal and mineral waters, in Barnes, H. L., ed., Geochemistry of hydrothermal ore deposits: New York, Holt, Rinehart, and Winston, p. 575-631.

White, D. E., Fournier, R. O., Muffler, L. J. P., and Truesdell, A. H., 1975, Physical results of research drilling in thermal areas of Yellowstone National Park, Wyoming: U.S. Geological Survey Prof. Paper 892, $70 \mathrm{p}$.

White, D. E., Muffler, L. J. P., and Truesdell, A. H., 1971, Vapordominated hydrothermal systems compared with hot-water systems: Econ. Geology, v. 66, p. 75-97.

Wollast, R., MacKenzie, F. T., and Bricker, O. P., 1968, Experimental precipitation and genesis of sepiolite at earth-surface conditions: Am. Mineralogist, v. 53, p. 1645-1662.

Yanagisawa, M., Takeuchi, T., and Suzuku, M., 1973, Flameless atomic absorption of antimony: Anal. Chim. Acta, v. 64, p. 381386.

Zeikus, J. G., and Brock, T. D., 1972, Effects of thermal additions from the Yellowstone Geyser Basins on the bacteriology of the Firehole River: Ecology, v. 53, p. 283-290. 